\title{
Phylogenetic Aspects and New Descriptions of Spicule-Bearing Hadromerid Sponges with a Secondary Calcareous Skeleton (Tetractinomorpha, Demospongiae)
}

\section{J. REITNER}

\section{Introduction}

In contrast to the nonrigid modern demosponges and Calcarea, the sponges with an additional calcareous skeleton are extremely rare and restricted to dark and cryptic habitats within tropical reefs and submarine caves of the Mediterranean Sea. Only 14 recent genera of the so-called sclerosponges or coralline sponges and pharetronids are known (nine demosponges and five calcisponges) (Kirkpatrick 1908, 1910, 1911; Lister 1900; Döderlein 1897; Vacelet 1964, 1981; Hartman and Goreau 1970, 1975; Hartman 1979, etc.). Coralline sponges are quite common in the fossil record. During the Paleozoic and Cretaceous they were important reefbuilders or members of reefal communities. Traditionally, most of these sponges are classified as Stromatoporoidea, Chaetetida, Sphinctozoa, or Pharetronida. These terms describe only the type of soft tissue arrangement within these particular sponge skeletons and have no taxonomic value (Reitner 1987a,b,c; Wood 1987). Hartman and Goreau (1972) have established a new class of sponges which incorporates all sponges with siliceous spicules and an additional calcareous basal skeleton. However, based on the similarities of the spicules and soft tissue with nonrigid demosponges and Calcarea, van Soest (1984), Vacelet (1985), Reitner (1987a,b,c) and Wood (1987) have proposed a polyphyletic origin of the class "Sclerospongiae". It is possible to recognize different phylogenetic lineages of fossil and modern calcified demosponges which demonstrate in some cases extremely long-ranging clades (Reitner and Engeser 1985, 1987; Wood et al. 1989).

The purpose of this chapter is to demonstrate the polyphyletic nature of calcified hadromerida and to establish a phylogenetic model for this group.

\section{Material and Methods}

This study is based on the type material of the species Boswellia mortoni Gray (1980) (British Museum of Natural History (BMNH) no. R4429), Cassianothalamia zardini Reitner(1987b) (Institut für Paläontologie Freie Universität Berlin (IPFUB) no. 87/1/2) and other newly collected fossil material deposited within the IPFUB. The Recent counterparts were loaned from the BMNH, Institute of Taxonomic Zoology Amsterdam (ITA), and the marine lab Endoume, University 
of Marseille. Some were collected in Bermuda and the western part of the Mediterranean Sea near Banyuls sur Mer.

From all sponges thin- or histological sections were made and studied under a light microscope. The histological sections were stained with acid fuchsin and toluidine blue to study the soft tissue arrangement. In order to separate the spicules from the soft tissue, the sponges were treated with $\mathrm{H}_{2} \mathrm{O}_{2}$. To expose the spicules from the calcareous basal skeletons, polished surfaces were etched with 5\% Tritriplex-III solution $\left(\mathrm{C}_{10} \mathrm{H}_{14} \mathrm{~N}_{20} 18 \times 2 \mathrm{H}_{2} \mathrm{O}\right)$.

After 1 day of treatment the samples were cleaned with distilled water and then dried. Subsequently the etched surfaces were examined with a scanning electron microscope (SEM). Micro- and ultrastructures were studied on freshly broken surfaces. The chemical analyses of the calcitic skeletons were performed with atomic absorption spectroscopy (AAS), energy dispersive X-ray analysis (EDAX), and electron microprobe analysis.

\section{Systematic Position of the Hadromerida}

The Hadromerida are sponges which possess monactine megascleres as tylostyles or subtylostyles. The microscleres are always asters or modified asters. The megascleres are generally organized in a radial pattern but, in most cases, this radial pattern is ill developed. The microscleres, if present, are concentrated within the cortical zone of the sponge. Within the Hadromerida, spongin is present but never as fibers.

The hadromerid sponges are oviparous, wherever they have been observed. Based on spicule morphology, oviparity, and simple spongin, these particular sponges are classified within the subclass Tetractinomorpha (Levi 1973; Bergquist 1978). The Hadromerida are one of the best-characterized sponge groups.

\section{Skeletal Types of Extant Hadromerid Sponges}

Within the Hadromerida a reduction of the spicular skeleton is observed in various families. This reducted part of the primary skeleton is substituted by strong collagenous skeletal elements. It is possible to distinguish different stages of sclere reduction:

a) reduction of microscleres (Suberitidae, Polymastidae),

b) reduction of megascleres (Chondrilla) or a partial reduction, as seen in Spirastrella,

c) reduction of micro- and megascleres (Chondrosia)

A special type of indirect skeletal formation is observed within some species of Spirastrella and the genus Cliona. Cliona excavates burrows in any calcareous material and the entire sponge, except the marginal inhalant and exhalant systems, lives inside the burrows (Rützler 1974; Keupp and Reitner this Vol.). 
Calcareous basal skeletons, the main topic of this chapter, are observed only within the extant genus Acanthochaetetes, which possesses a spicular skeleton similar to Spirastrella (Reitner and Engeser 1987). Within the fossil record, calcareous basal skeletons are observed in several taxa.

\section{Fossil and Modern Hadromerida with a Secondary Calcareous Skeleton}

Remarks:

The author has decided to erect new genera for new fossil taxa. The distinct types of calcareous skeletons of these particular fossils should be recognizable as morphotypes for all fieldworking paleontologists, since spicules are not seen or preserved in all cases. Using the principles of phylogenetic systematics new genera must not be erected in all cases of calcareous skeletons.

\section{Family Suberitidae Schmidt}

The Suberitidae are characterized by tylostyle and subtylostyle megascleres and rare microstrongyle microscleres. The typical hadromerid radial arrangement of the scleres is present only at the surface of the sponge. In the center part of the sponge the orientation of the spicules is confused. The spicules which cover the exhalant canals often show a loose plumose orientation (Fig. 3a,b).

\section{Chaetetes (Boswellia) mortoni Gray (Figs. 1,2)}

1980 Chaetetes (Boswellia) mortoni Gray, p. 808, P1. 103

This species from the Lower Carboniferous (Lower Asbian) from Northern Wales is the oldest known coralline sponge with hadromerid character.

Primary skeleton:

Chaetetes mortoni possesses tylostyle megascleres (length $170-210 \mu \mathrm{m}$ ) which are arranged in bundles as observed in Suberites (Fig. 3a,b). These bundles are relicts of a radial pattern, characteristic of the Hadromerida.

Microscleres are not observed. The spicules are preserved as diagenetic silica or calcite (Fig. 2c).

Secondary skeleton:

The spicules are covered by a clinogonal ("water jet" structure, or fasicular fibrous) calcite (probably Mg-calcite) (Fig. 1c), which is common in coralline sponges. In this case the secondary skeleton is analogous to the primary collageous/spicular skeleton, which is substituted by Mg-calcite (Fig. 1b). The entire basal skeleton exhibits a chaetetid structure: that means the calicles are separated by tabulae which mark the boundary between the living sponge and the dead part of the basal skeleton (for measurements see Gray 1980, p.809). 

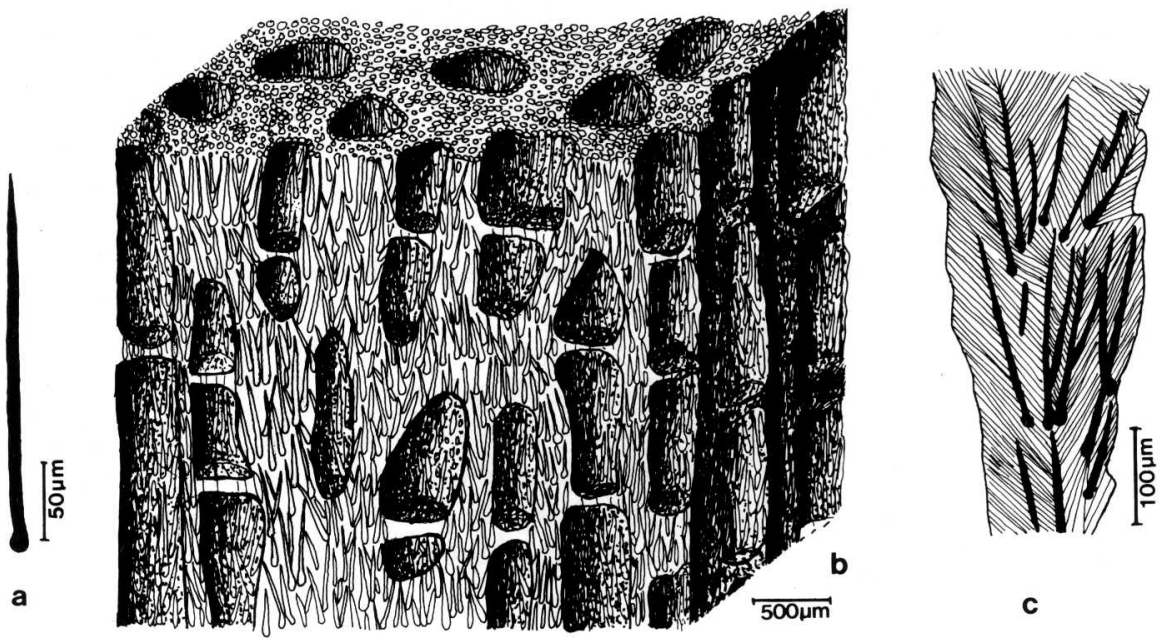

C

Fig. 1. Chaetetes (Boswellia) mortoni Gray. a Tylostyle megasclere. b Reconstruction of the spicular arrangement which is similar to the extant genus Suberites. c Primary and secondary skeleton of a single wall

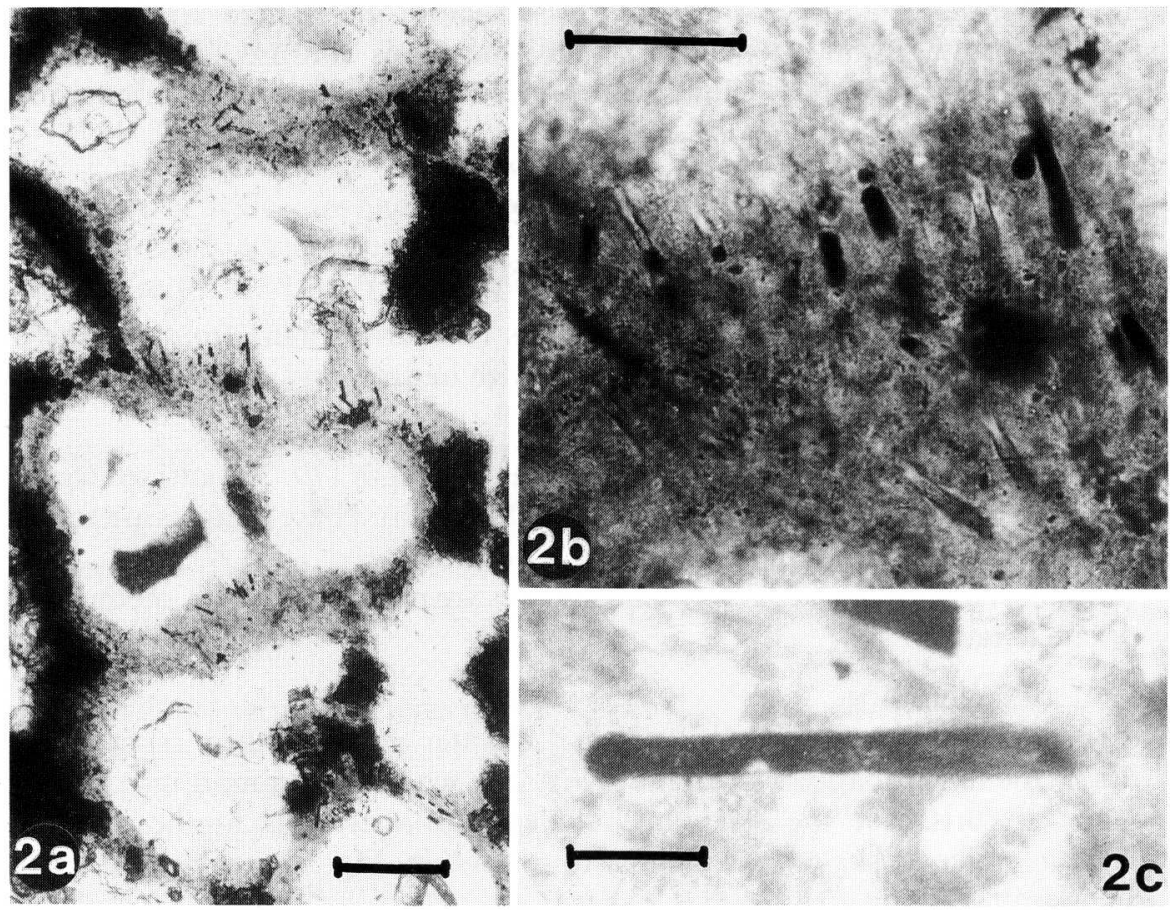

Fig. 2. a Horizontal section of Ch.(B.) mortoni Gray demonstrating the spicule bundles. Gray's paratype (British Museum Nat. Hist. no R 4429). Scale $=200 \mu \mathrm{m}$. b Detail of a Spicules partly preserved in pyrite. Scale $=100 \mu \mathrm{m}$. c Tylostyle megasclere of Ch.(B.) mortoni. Scale $=50 \mu \mathrm{m}$ 

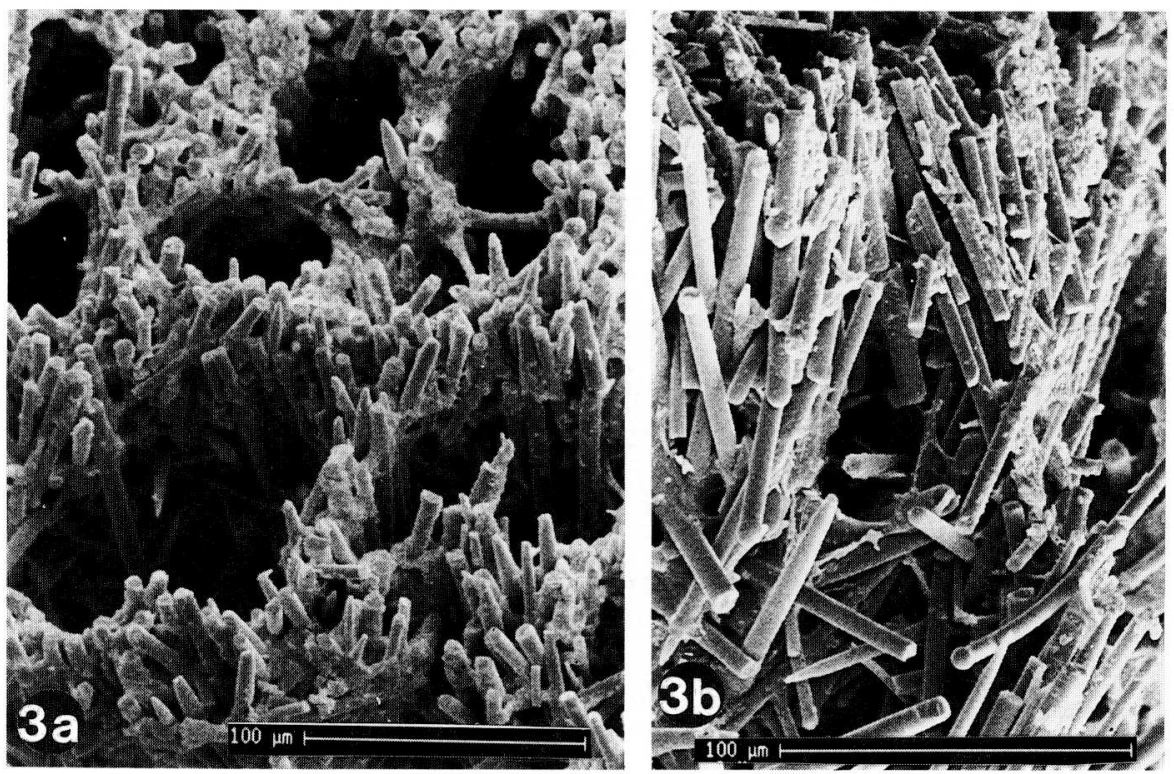

Fig. 3. a Suberites carnosus; view on the surface of the dermal layer. Corallingene, Banyuls sur Mer, marine station Arago. b Detail of dermal layer of the specimen of a. The spicules are arranged in a subradiate way

Remarks:

The spicular skeleton of Chaetetes mortoni is comparable with the dermal layers of the families Suberitidae and Polymastiidae. Both groups have only rare microscleres and tylostyle megascleres. Microscleres are not known from $C$. mortoni. Significant are the bundles of megascleres, arranged in a loose perpendicular orientation, which is characteristic for the Suberitidae (Fig. 3a,b). This species is the oldest known hadromerid sponge.

\section{Chaetetopsis favrei (Deninger 1906) (Figs. 4,5)}

1906 Monotrypa favrei Deninger, p. 64, Pl. VI, Fig. 5a,b

1930 Chaetetopsis favrei (Deninger); Peterhans, p. 35, Pl. I,II

1970 Chaetetopsis favrei (Deninger); Fischer, p. 190

1979 Chaetetopsis favrei (Deninger); Kazmierczak, Figs. 2-4

This early Cretaceous coralline sponge species is very common in Barremian and Aptian reefs. Kazmierczak (1979) reported the first monaxonic spicule remains from a specimen from the Crimea. The spicules are preserved in rows of framboid pyrite. The exact shape of the spicules is not shown in this particular specimen. Newly collected material from the Albian of Greece allows one to distinguish the spicule type and arrangement, as well as the microstructure of the calcareous skeleton. 

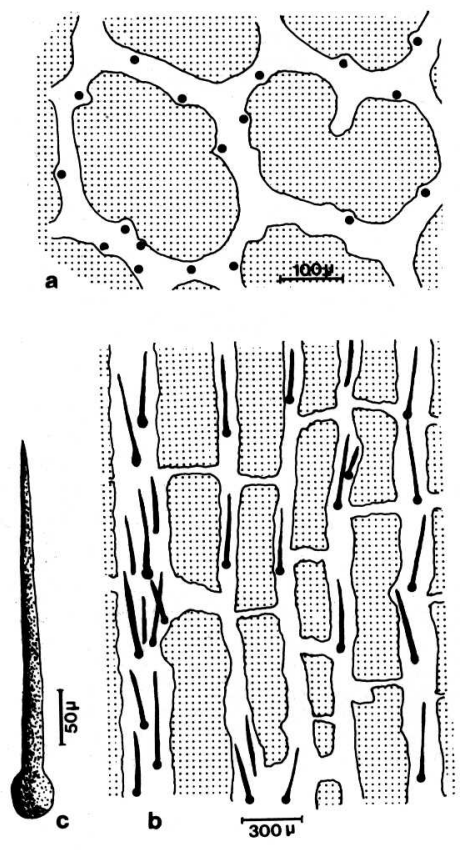

Fig. 4. Chaetetopsis favrei (Deninger). a Horizontal section exhibiting the spicule arrangement (black dots). Redrawn from Kazmierczak 1979. b Vertical cut of a specimen from Arachova (Aptian? from Greece). c Tylostyle megasclere of the specimen from Arachova

Primary skeleton:

The tylostyle spicules (120-450 $\mu \mathrm{m}$ length, 5-10 $\mu \mathrm{m}$ thick) (Figs. 4c, 5c-e) are arranged in loose bundles (Figs. 4,5c). The specimen from the Barremian of Crimea covers partially the inner wall of the calicles (Fig. 4a). Horizontal spicule elements and microscleres are not observed. The loose arrangement of the spicules indicates a prominent collagenous skeleton which has a matrix function for the secondary calcareous skeleton.

Secondary skeleton:

The entire basal skeleton demonstrates a chaetetid structure (Figs. 4c, 5a). The calicles are subdivided by tabulae. The tabulae are regular and thin (10-20 $\mu \mathrm{m})$ and composed of minimicrite. The vertical wall exhibits a fasicular fibrous microstructure, as seen in Paleozoic Chaetetes (Fig. 5b). The thickness of the wall varies only a little $(300-700 \mu \mathrm{m})$. The spicules are intramural. Some of the spicules protrude from the calcitic wall. In this case the spicules were primarily not covered

Fig. 5. Chaetetopsis favrei (Deninger). a Vertical section of the specimen of Arachova (near Delfi, Greece; Aptian? component in an Eocene "Qphiolithe Conglomerate"). Scale $=200 \mu \mathrm{m}$. b Fascicular/hemispherulitic microstructure of the calicle wall of the Arachova specimen. Scale $=75 \mu \mathrm{m}$. c Tylostyle megasclere of the Arachova specimen. The spicule is partly preserved by pyrite spherules (framboid pyrite, probable formed by bacteria). Scale $=50 \mu \mathrm{m}$. d Tylostyle megasclere of the Arachova specimen. The spicule is preserved by a granular calcite. Scale $=50 \mu \mathrm{m}$. e Intramural tylostyle megascleres of the Arachova specimen. Scale $=75 \mu \mathrm{m}$ 

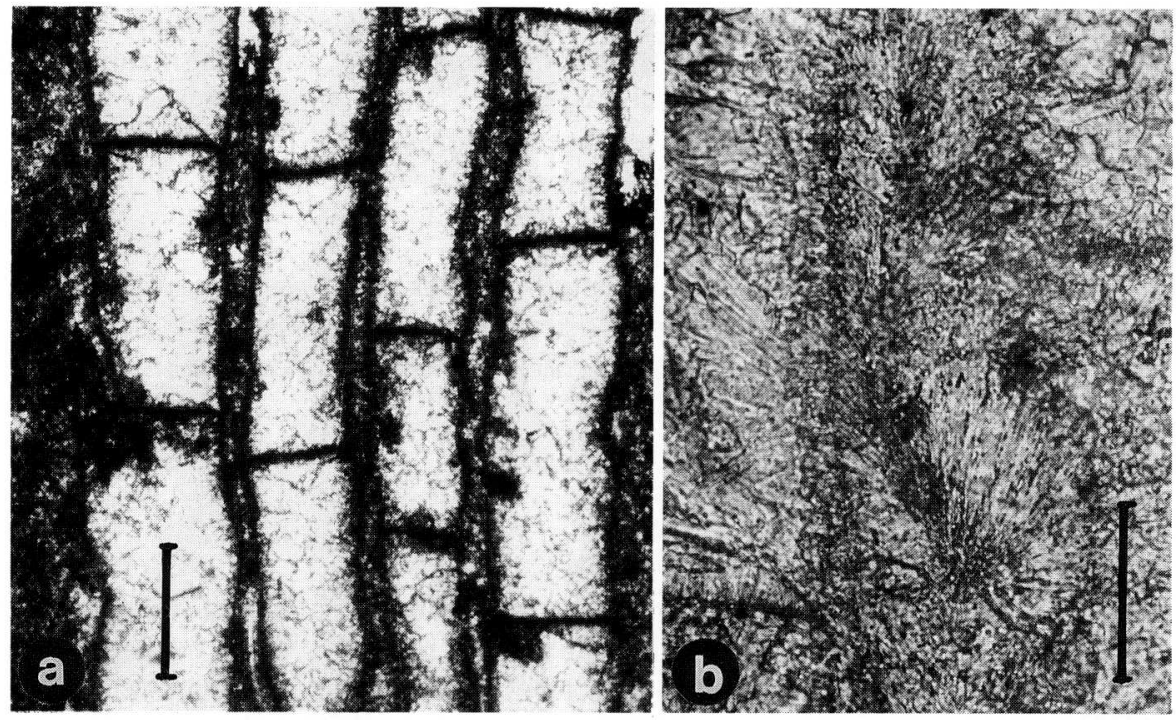

15. $15 \%$

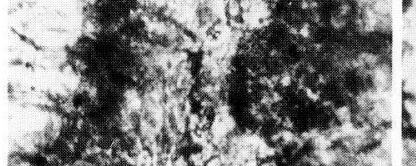

6695

24. tros 5

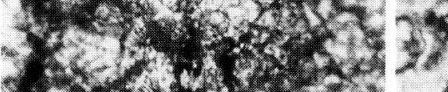

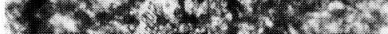

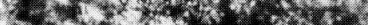

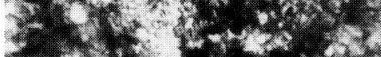

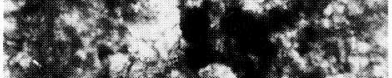

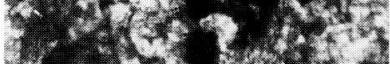

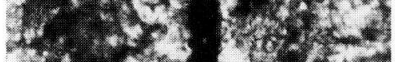

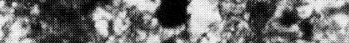

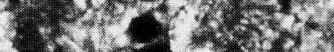
(2)

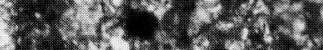

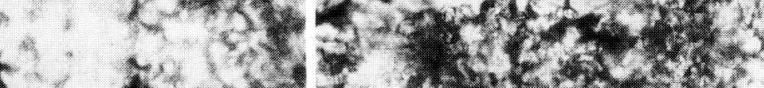

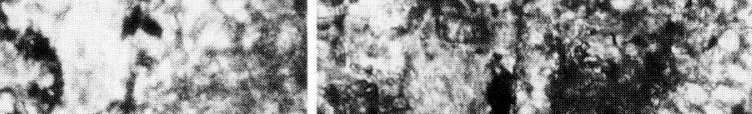

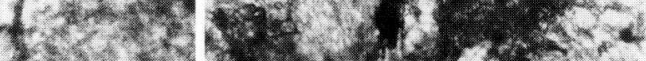
$f^{3}$

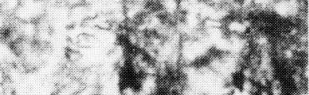

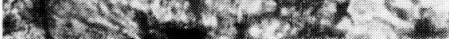

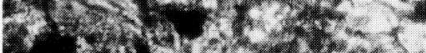

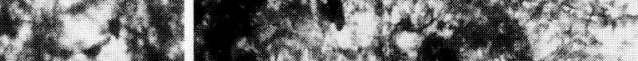

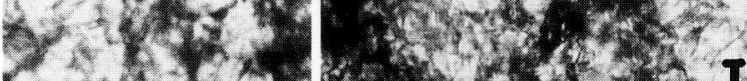
5. 340 100

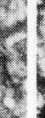
2. $36 y^{2}+3 x=2$

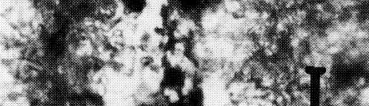
$\left.(3,)^{2}, x^{2}\right)^{2}$

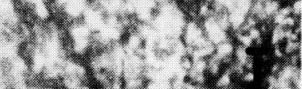

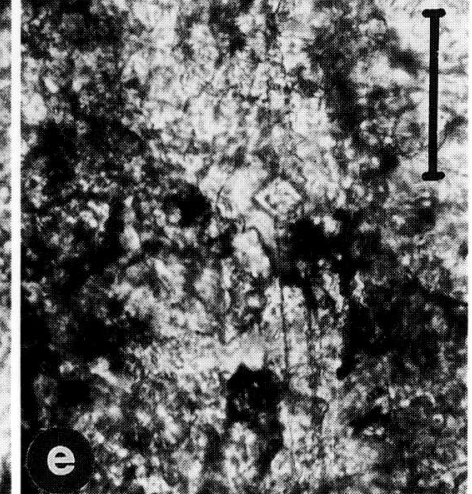

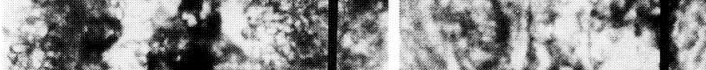

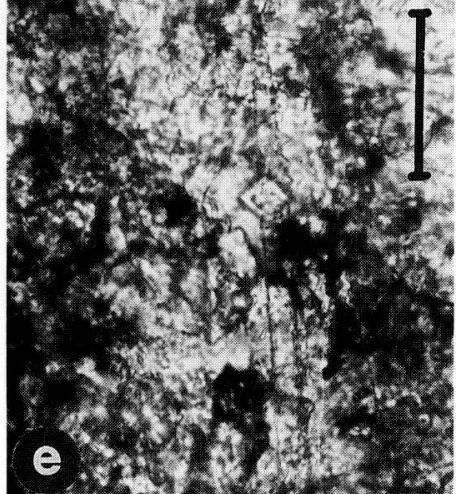
c 6.4 . 
by collagenous soft tissue. The basal skeleton reflects the primary sponge skeleton. The primary microstructure is, in most cases, not recognizable. The skeleton exhibits a diagenetic granular or blocky calcite. Only in a few examples are relicts of the original structure observed. Based on this observation, an aragonitic primary mineralogy is very probable.

\section{Remarks:}

Spicule type and the relict radially oriented spicules point toward a classification within the hadromerids. The axially oriented intramural tylostyle scleres indicate that Chaetetopsis as well as Chaetetes mortoni Gray is also a member of the family Suberitidae.

\section{Family Chondrosiidae Schulze}

The Chondrosiidae are sponges with a strong collagenous skeleton lacking, in most cases, the spicular skeleton. Only aster microscleres, mostly euasters, are present in the genus Chondrilla. Megascleres are unknown. All members of this group are characterized by a strong cortex in which the microscleres are enriched if present. The cortex is formed by fibrillar collagen. The sponges are encrusting or massive.

\section{Genus Chondrochaetetes n.gen.}

Type species: Chondrochaetetes longitubus n.gen. n.sp.

Derivatio nominis: Combined from the hadromerid family Chondrosiidae "Chondro-" and the term "Chaetetes" for basal skeletons with subdivided by tabulae into calicles.

\section{Diagnosis:}

Hemispherical sponges with a chaetetid secondary calcareous basal skeleton. The microstructure of the vertical walls is fascicular fibrous. The tabulae are micritized. Intramural aster microscleres are common within the vertical walls.

\section{Chondrochaetetes longitubus n.gen., n.sp. (Fig. 6a-e)}

Derivatio nominis: After the Latin word "longitubus" since this species possesses very long calicles.

Fig. 6. a Chondrochaetetes longitubus n.gen. n.sp., holotype from the Carboniferous of the USSR. Horizontal cut exhibiting asterose microscleres (arrows) (BMNH no. R 27318). Scale $=500 \mu \mathrm{m}$. b Vertical section of the holotype of Chondrochaetetes. The very thin tabulae and the calicle wall are covered by a granular calcitic cement. Scale $=500 \mu \mathrm{m}$. $\mathrm{c}$ Detail of the calicle wall of Chondrochaetetes demonstrating the fascicular fibrous wallstructure and intramural asterose microscleres. Scale $=200$ $\mu \mathrm{m}$. d Intramural asterose microsclere of Chondrochaetetes. Preservation is in granular calcite. Scale $=50 \mu \mathrm{m}$. e Intramural asterose microscleres (euasters?) of Chondrochaetetes. Black cores of the spicules are pyrite. Some of them exhibiting relicts of the star rays (arrow). Scale $=50 \mu \mathrm{m}$ 


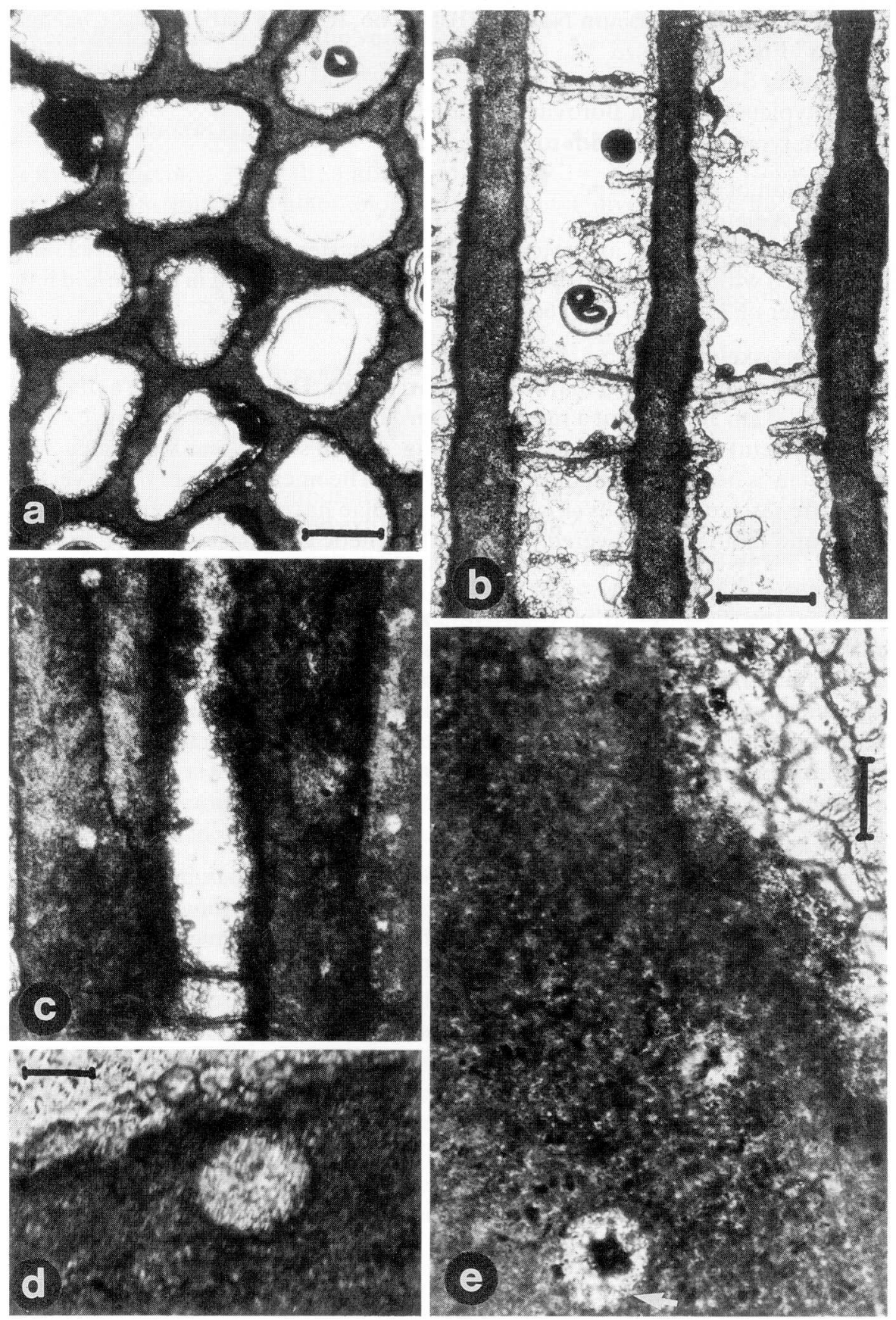


Holotype: British Museum Natural History no. R 27318 (labeled as "Chaetetes radians" Fischer).

Diagnosis: See genus diagnosis

Locus typicus: Kaluga Borovitch, Yaldai, Russia

Stratum typicum: Carboniferous Limestone

Description of the holotype:

Primary skeleton:

The observed spicules are asters, probably euaster, and they are irregularly distributed within the calcitic wall. The spicules are preserved in calcite and have a diameter of 25-35 $\mu \mathrm{m}$ (Fig. 6c-e).

Secondary skeleton:

The uncut specimen has a diameter of nearly $5 \mathrm{~cm}$. The calicles have a diameter of 200-300 $\mu \mathrm{m}$ and exhibit a radial pattern. They are separated only by few ( 3 or 4 tabulae $/ \mathrm{cm}$ ) thin (ca. $30 \mu \mathrm{m}$ ) tabulae (Fig. $6 \mathrm{~b}$ ). In some areas a dense packing of tabulae is observed with more than $10 / \mathrm{cm}$. The microstructure of the vertical walls are fascicular fibrous (Fig. 6c). The tabulae have a minimicritic structure. Walls and tabulae are covered by a late diagenetic granular cement (Fig. 6b).

Differential diagnosis:

The new species differs from Chaetetes mortoni in possessing aster microscleres only. Other differences of the new species Calcistella tabulata include a missing canal system within the calicle wall. The microstructure of Chondrochaetetes is fascicular fibrous in contrast to the dense micritic structure of Calcistella. The microscleres are significantly smaller with a mean diameter of $30 \mu \mathrm{m}$ in comparison with microscleres of Calcistella, which exhibit a mean diameter of $55 \mu \mathrm{m}$.

Remarks:

This Carboniferous spicule-bearing calcified demosponge has, based on the aster (euaster?) scleres, close affinities to the family Chondrosiidae. However, an enrichment of microscleres in any zone of the chaetetid skeleton is not observed and there are no traces of a dermal layer. The spicules are irregularly distributed, probably caused by early diagenetic dissolution of the scleres and rapid epitactical cementation of the molds (cf. Reitner $1987 \mathrm{~b}, \mathrm{c}$ ). The new form is probably related to the genus Chondrilla, which contains euaster microscleres only. In contrast to the tylostyle megasclere-bearing species, the chaetetid basal skeleton of this particular form is not analogous to the primary spicular/organic skeleton.

Genus Calcistella n.gen. (Fig. 7a-d)

Type species: Calcistella tabulata n.gen., n.sp.

Derivatio nominis: After the Latin words "calcium" and "stella" = star.

Diagnosis:

The aster microscleres-bearing sponge possesses a modified chaetetid secondary micritic skeleton. Diameter of the calicles is exceptionally large. The calicle walls 
are structured by numerous pores and canals. The asters are restricted to the mineralized micritic part of the vertical walls.

Differential diagnosis: See species description

\section{Calcistella tabulata n.gen., n.sp. (Fig. 7a-d)}

Derivatio nominis: After the Latin word "tabula" = plate Holotype: Institut für Paläontologie der Freien Universität Berlin (IPFUB, JR1/89).

Locus typicus: Arachova near Delfi, Greece; sampled by H. Keupp Stratum typicum: Albian component within the "Ophiolithe-Conglomerate" of Eocene age.

\section{Diagnosis: See generic diagnosis}

Description of the holotype:

Primary skeleton:

The spicular skeleton is composed of aster microscleres only (Fig. 7c,d). The asters are preserved as spherules and exhibit only, in a few cases, relicts of spines. Based on this observation, the asters were probably euasters. The diameter of the spherules varies little $(50-65 \mu \mathrm{m}$ with a mean value of $55 \mu \mathrm{m})$. The asters are restricted to dark micritic areas within the calicle wall (Fig. 7c). The dark areas form a more or less irregular network within the vertical skeletal elements, interrupted by pores which mark complicated canal systems inside the calicle wall. The canal pores are separated from the dark micritic areas by thin granular sparitic layers. The diameter of the canal systems are $140-400 \mu \mathrm{m}$. The enrichment of spicules in the micritic parts only indicates a thick fibrillar primary collagenous skeleton. The canal systems are probably excurrent canals. Spicules are never observed within the tabulae.

Secondary skeleton:

The entire sponge exhibits a hemispherical chaetetid structured basal skeleton ( 6 $\mathrm{cm}$ diameter measured in thin section) with extraordinarily big tubes (Fig. 7a,b). The diameter of the tubes varies from $1.2-3 \mathrm{~mm}$ (mean $1.8 \mathrm{~mm}$ ). The microstructure of tabulae and the vertical wall is micritic. Sparitic lamellae are common above the tabulae, at the base of the tubes, and within the excurrent canals (Fig. $7 \mathrm{~b}$ ). These ca. $20 \mu \mathrm{m}$ thick lamellae are interrupted by thin micritic layers and mark the upward migration of the living sponge tissue. The sparitic layers mark the gap between the secondary skeleton and pinacoderm of the living sponge. The primary mineralogy of the basal skeleton was a high $\mathrm{Mg}$-calcite. All associated aragonitic organisms are recrystallized. EDAX analysis show $\mathrm{Mg}$ anomalies within the wall and support this assumption.

Remarks:

This type of chaetetid basal skeleton is analogous to the primary collagenous skeleton of the living sponge. The collagenous skeleton was probably very strong and became calcified synvivo, as indicated by the sparitic growth of lamellae. The microscleres are concentrated within the thick fibers only. The calicle wall was 

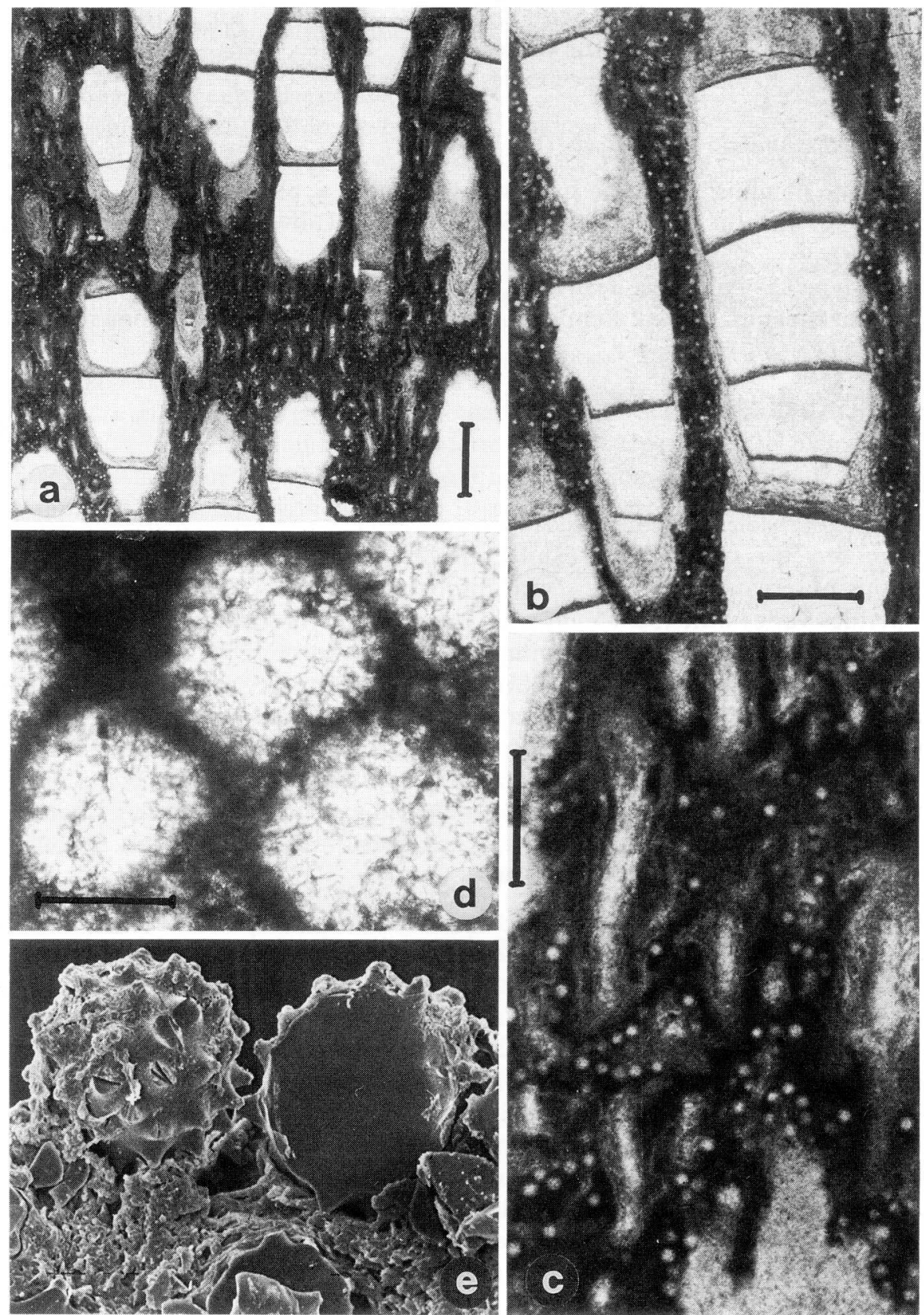
also penetrated by choanosomal soft tissue with prominent excurrent canals. This is in contrast to all other observed chaetetid sponge skeletons.

The very big microscleres, the strong collagenous skeleton, and the canal systems are comparable with the family Chondrosiidae, particularly with the genus Chondrilla (Figs. 7e,10b). The euasters of Chondrilla grandistellata show dimensions as measured in Calcistella (Figs. 7e,10b). The mineralized internal canal systems were probably formed by the endopinacoderm layer. The calical walls became mineralised by calcification of the collagenous fibers, as observed in the extant coralline sponge Vaceletia (Reitner 1987b). The tabulae were probably formed by the exopinacoderm layer, as observed in the extant hadromerid sponge Spirastrella (Acanthochaetetes) wellsi. This may explain the different observed structures of the calcitic secondary rigid body.

\section{Differential diagnosis:}

This new form differs from the genus Chondrochaetetes n.gen. by having a complicated excurrent canal system within the calicle walls, micritic microstructure, and aster microscleres $55 \mu \mathrm{m}$ in diameter in contrast to $30 \mu \mathrm{m}$ measured in Chondrochaetetes. The chaetetid species from the early Cretaceous of China, Pseudomillestroma reticulata Deng (Deng 1982), differs from the new species in having smaller asters and missing a canal system inside the calicle wall.

\section{Genus Calcichondrilla n.gen. (Fig. 8a-d)}

Type species: Calcichondrilla crustans n.gen., n.sp.

Derivatio nominis: After the Latin word "Calcium" and the genus name "Chondrilla" for hadromerid sponges which have only euaster microscleres.

Diagnosis:

Crustose sponges which have large aster microscleres only. The scleres are enriched in the primary strong collagenous parts of the skeleton. Prominent excurrent canals do exist. The entire primary collagenous skeleton of the sponge is calcified.

Differential diagnosis: See species diagnosis

Calcichondrilla crustans n.gen., n.sp. (Fig. 8a-d)

Derivatio nominis: After the Latin word "crustae" for crusts. Holotype: Deposited in the IPFUB, JR2/89 (Fig. 8a-d)

Fig. 7. a Tangential cut of the basal skeleton of Calcistella tabulata n.gen. n.sp. (holotype) from the Aptian? of Arachova (Greece). Within the thick calicle walls the characteristic canal systems are visible. Scale $=1 \mathrm{~mm}$. b Calicles of Calcistella exhibiting the tabulae and the growing lamellae of the upward moving soft tissue preserved in a granular calcite. The calicle wall exhibiting numerous asterose microscleres. Scale $=1 \mathrm{~mm}$. c Detail of a showing the internal canal systems and the spicules. Scale $=800 \mu \mathrm{m}$. d Calcite filled scleres molds (euasters?) of Calcistella. Scale $=50 \mu \mathrm{m}$. e Euaster microscleres of Chondrilla grandistellata (SEM microgaph). Compare d 


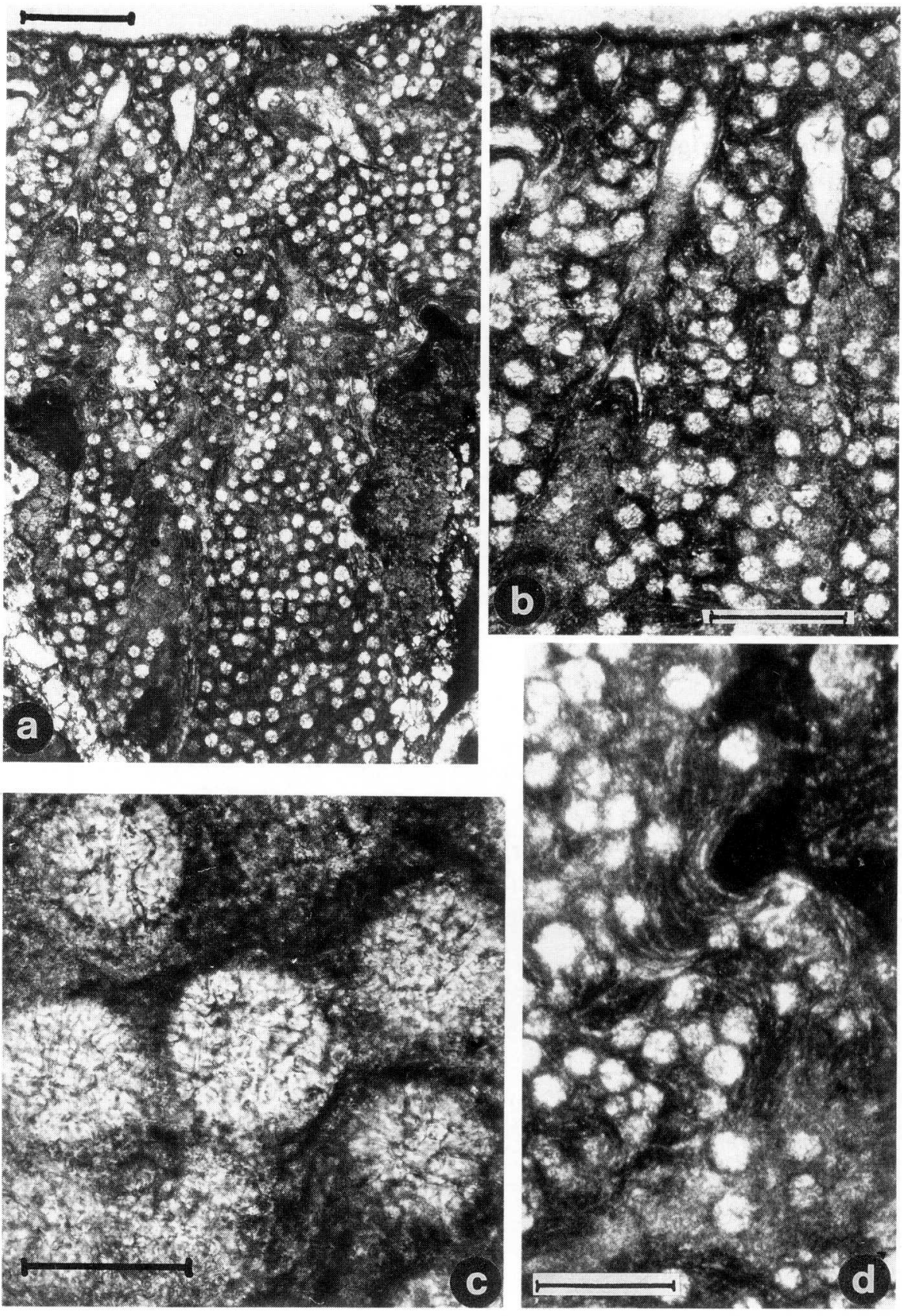

Fig. 8. a Total view (oblique cut) of the holotype of Calcichondrilla crustans n.gen. n.sp. from the Middle Albian of Saturarran (northern Spain). Scale $=1 \mathrm{~mm}$. b Detail of a exhibiting the excurrent canals and the spicular skeleton. Scale $=400 \mu \mathrm{m}$. c Probably euasters of Calcichondrilla. Molds preserved in a polycrystalline calcite. Scale $=100 \mu \mathrm{m}$. d Lamellar structure of the calcified primary strong collagenous skeleton of Calcichondrilla . Scale $=200 \mu \mathrm{m}$ 


\section{Paratypes: Deposited in the IPFUB, JR3/89 (Fig. 9a-c)}

Locus typicus: Beach of Saturarran, Basque Lands in Northern Spain Stratum typicum: Middle Albian clast from a debris flow of Late Albian age.

Description of the holotype:

Primary skeleton:

The incomplete specimen is found in a thin section and is $5 \mathrm{~mm}$ in diameter. The specimen is cut obliquely and shows different niveaus of the excurrent canals (Fig. $8 \mathrm{a}, \mathrm{b})$. The diameter of the excurrent canals varies between 100 and $400 \mu \mathrm{m}$. The excurrent canal systems are radially arranged. The spicules are enriched in areas between the canals. The inner surface of the canals are free of spicules (Fig. 8b,d). The spicules are big euasters $(75-100 \mu \mathrm{m}$ diameter, mean $80 \mu \mathrm{m})$. The asters are preserved as calcitic spherules which exhibit, in some cases, relicts of short rays (Fig. 8c). The entire skeleton demonstrates irregular lamellae which reflects the fibrillar character of the strong primary collagenous structures (Fig. 8d). No separate dermal layer enriched in microscleres is present.

Secondary skeleton:

The whole primary skeleton of the sponge is calcified. The entire skeleton is becoming calcified and is analogous to the primary collagenous skeleton. The primary mineralogy was a high $\mathrm{Mg}$ calcite. The microstructure is irregular. In most cases, the calcite is brownish in color.

\section{Description of paratype I (Fig. 9a,b)}

The specimen was found in a thin section of a Lower Albian rock of the Euzkadiella-facies of the red lagoonal rudist limestone of Ereño, $30 \mathrm{~km}$ west of Saturraran. Calcicondrilla forms a thin crust (mean $200 \mu \mathrm{m}$ ) on the surface of an already dead specimen of the coralline haplosclerid sponge Euzkadiella erenoensis. In some areas the sponge exhibits small buds $(200-250 \mu \mathrm{m})$. The diameter of the scleres varies from $75-115 \mu \mathrm{m}$. The secondary skeleton has the same irregular brownish calcite. Because of the thin crust, no excurrent canals are observed.

\section{Description of paratype II (Fig. 9c)}

The specimen was cut horizontally and is located in a thin section of the Lower Albian gray reef limestone of Ereño. Calcichondrilla crusts on microsolenid corals of the Acanthochaetetes community. The thick part of the crust exhibits horizontal cuts of the excurrent canals. The very thin crusts overgrow biogenes, similar to bryozoans and algae. On the sponge a thecidellinid brachiopod is cemented with its fixed valve. This indicates the rigid character of the living sponge. The spicules are very densely arranged. Relict structures of the collagenous skeleton, as seen in the holotype, are not observed. The entire sponge represents first-order framebuilders of the Acanthochaetetes community.

Remarks:

The new genus Calcichondrilla exhibits many similarities with the genus Chondrilla (Figs. 7e, 10a,b) especially the type of microscleres and the internal structures. The species Chondrilla grandistellata bears the same large spicules (euaster diameter 75-150 $\mu \mathrm{m}$, mean $100 \mu \mathrm{m}$ ), the same type and dimensions of 

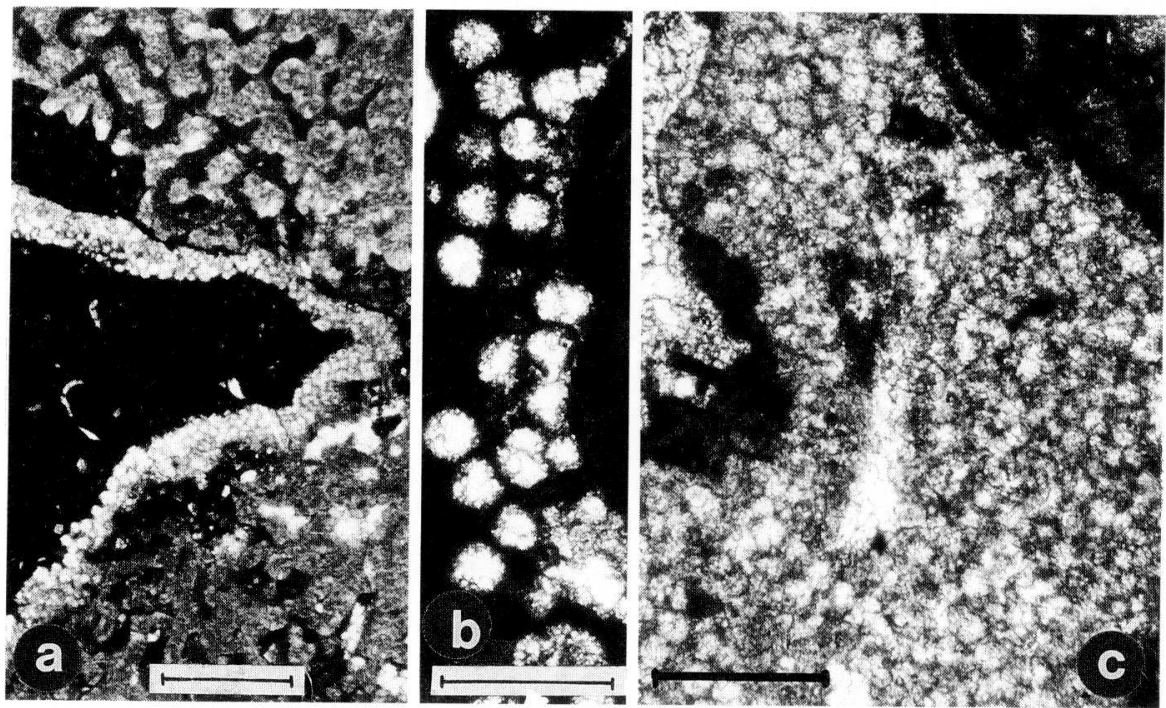

Fig. 9. a Paratype I of Calcichondrilla crustans n.gen. n.sp. from the Late Aptian "Red Rudist Limestone" of Ereño (northern Spain). The specimen is growing on the haplosclerid stromatoporoid Euzkadiella erenoensis Reitner. Scale $=1 \mathrm{~mm}$. b Detail of the spicular skeleton of paratype I. Scale $=300 \mu \mathrm{m}$. $\mathbf{c}$ Paratype II from the late Aptian gray reef limestone of Ereño (northern Spain). Scale = $500 \mu \mathrm{m}$

excurrent canals, and the same lamellae in the collagenous skeleton. All species of Chondrilla exhibit a characteristic dermal layer with an enrichment of spicules. Within the holotype no dermal layer is observed, but the thin crusts seen in paratype I and II may be interpreted as dermal layers. The systematic position within the family Chondrosiidae and a close relationship with the genus Chondrilla is very probable.

This species is part of the Acanthochaetetes community in the Aptian/Albian reefs (Reitner 1989a). Calcichondrilla is observed in northern Spain and within the Mural Limestone in Arizona (Reitner et al., in press).

Differential diagnosis:

The new species differs from Calcistella tabulata in having larger microscleres, the crustose growing pattern, and the lack of chaetetid basal skeleton. The closely related genus Chondrilla is missing a calcareous secondary skeleton.

Family Spirastrellidae Ridley \& Dendy 1886, Sensu Hentschel 1909

Emend. diagnosis

The Spirastrellidae are sponges with tylostyle megascleres and spiraster microscleres with great variability. The sponges encrust or form massive bodies. 


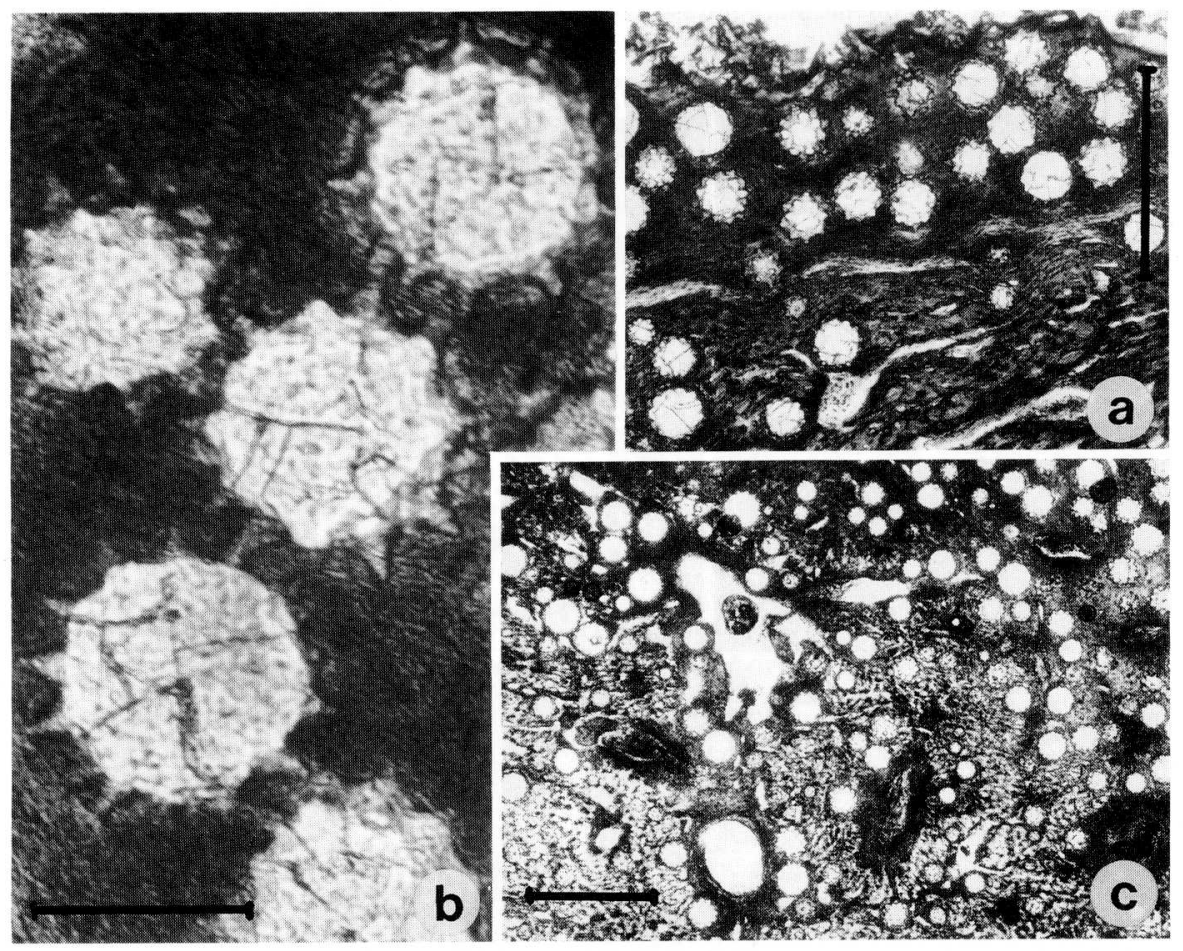

Fig. 10. a Vertical section through the dermal layer of Recent Chondrilla grandistellata exhibiting the enrichment of euasters. Scale $=500 \mu \mathrm{m}$. b Euasters of $\mathbf{a}$. Scale $=100 \mu \mathrm{m}$. $\mathbf{c}$ Choanosomal area of $\mathrm{Ch}$. grandistellata exhibiting the excurrent canals (compare Fig. 8b). Scale $=500 \mu \mathrm{m}$

In some cases prominent astrorhizal excurrent canals are visible on the surfaces of encrusting specimens (Figs. 11e-g, 13e).

In very few cases, excavating species are observed. High $\mathrm{Mg}$ calcite chaetetid-structured secondary skeletons are present in the subgenus Acanthochaetetes since the early Cretaceous (Jurassic?).

Genus Spirastrella Schmidt 1868

Synom. list: See Wiedenmayer 1977

Type species: Spirastrella cunctatrix Schmidt 1868

Subgenus Acanthochaetetes Fischer 1979 n.stat.

1970 - Acanthochaetetes n.gen. - Fischer, p. 199

1976 - Tabulospongia n.gen. - Mori, p. 5

Type species: Acanthochaetetes seunesi Fischer 1970

Remarks:

The validity of the taxon "Acanthochaetetes" is questionable. Rios and Almela (1944) have described a chaetetid sponge, Septachaetetes eocenus, from the Eocene of the southern Pyrenees, which exhibits a basal skeleton similar to Acanthochaetetes. New collections of this taxon do not show any spicule remains. 


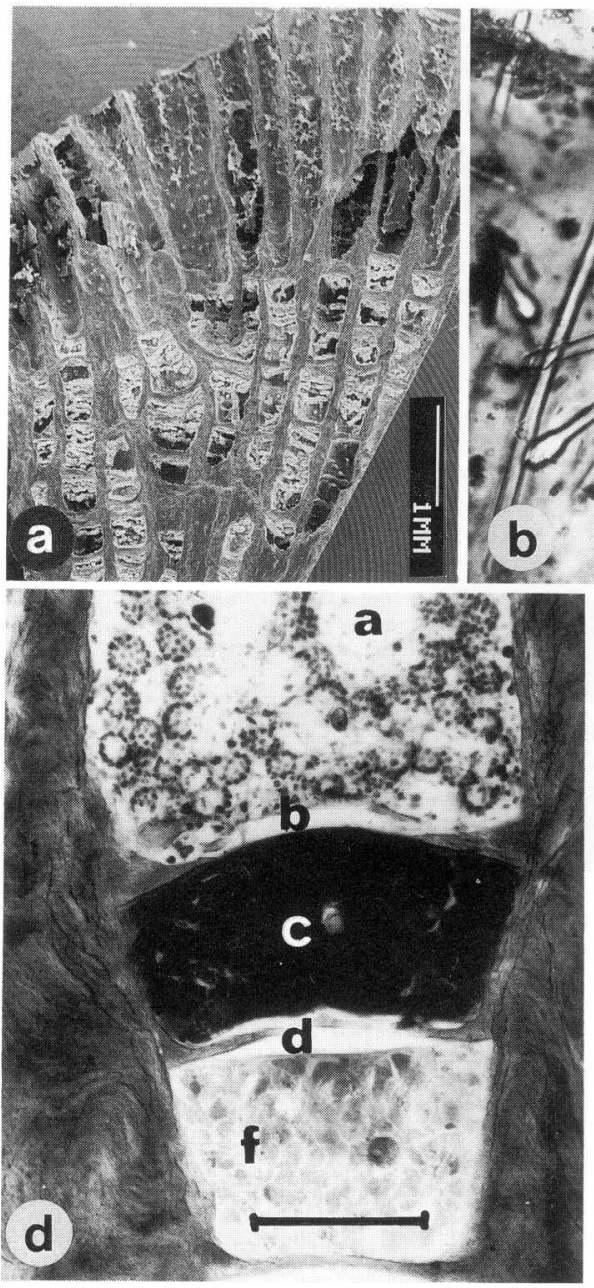

$36 x^{2} \sin ^{4}$

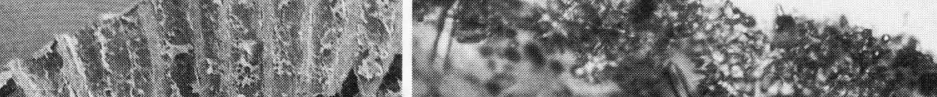

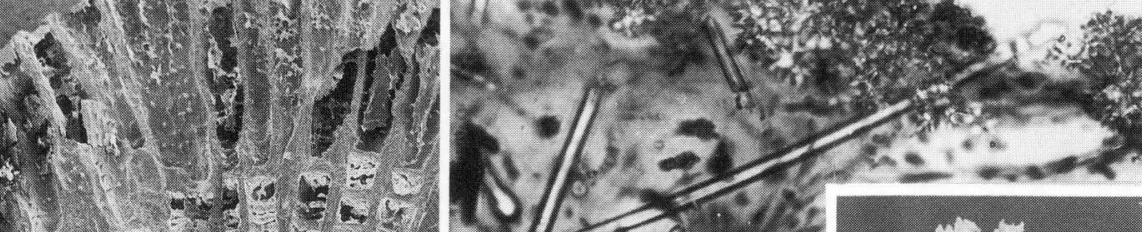

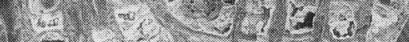

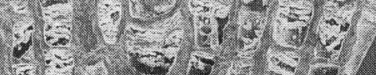

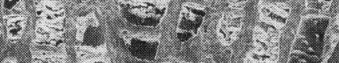

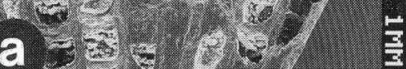

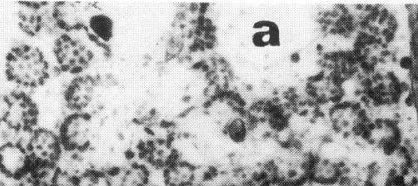
262 - 3 s a

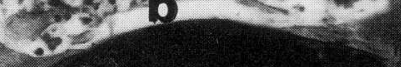
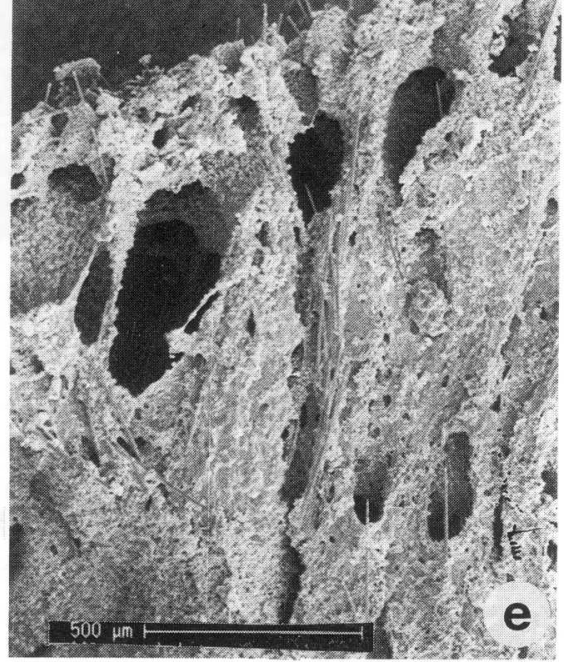

inisi

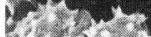

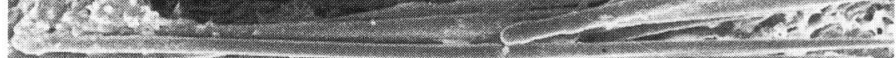

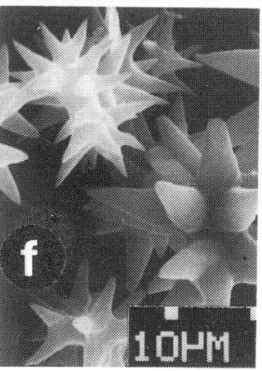


The calicles of this species exhibits only few spines, or in most cases, the spines are missing. Septachaetetes is the older synonym of Acanthochaetetes. If both taxons are similar, Septachaetetes is the valid name. But this question remains unanswered, because spicules are missing.

\section{Diagnosis:}

Sponges with tylostyle megascleres and spiraster microscleres are similar to Spirastrella with an additional high Mg-calcite chaetetid skeleton. Within the chaetetid secondary skeleton modified archaeocytes could be enclosed (modified gemmules).

Spirastrella (Acanthochaetetes) wellsi (Hartman and Goreau) n.comb. (Fig 1la-d)

Selected synonym list:

1975 - Acanthochaetetes wellsi n.sp. - Hartman and Goreau, pp. 2, Figs. 1-14.

1976 - Tabulospongia horiguchii n.gen., n.sp. - Mori, pp. 2, Pl. 1-5

1977 - Tabulospongia japonica n.sp. - Mori, pp. 2, Pl. 1-2

1987 - Acanthochaetetes wellsi - Reitner and Engeser, Figs. 1,3,5,7,8

Diagnosis: See subgenus diagnosis

Description of the primary skeleton and soft tissue arrangement:

The spicules are straight or slightly curved tylostyle megascleres (200-360 $\mu \mathrm{m}$ length) (Fig. 11b). In contrast to the extremely abundant microscleres the tylostyles are rare and demonstrate no preferred orientation. The microscleres are spirasters with extreme variation in shape (Fig. 11b,c).

Simple star-shaped scleres and all variations up to elongated amphiaster types are observed. The microscleres are enriched within the dermal layer (Fig. $11 \mathrm{~b}$ ). Collagen fibrils are present to anchor the soft tissue with the calcitic basal skeleton. These fibrils are seen only inside of the calicle wall and are never observed within the upper part of the spines and tabulae. Vacelet and Garrone (1985) describe additional intracellularly collagen fibrils and large bundles of fibrils between cells at the bottom of the calicles forming a matrix for the tabulae. Spongin is not observed.

Fig. 11. a SEM micrograph of Spirastrella (Acanthochaetetes) wellsi (Hartman \& Goreau) from Guam (Pacific) demonstrating the chaetetid character of the basal skeleton. Only the youngest part is free of early diagenetic cements. b Histological section of the dermal layer $S$.(A.) wellsi exhibiting the microscleres coat and the tylostyle megascleres (Vacelet coll.) Scale $=100 \mu \mathrm{m}$. c Spiraster microsclere of $S$.(A.) wellsi (SEM micrograph). d Lower part of the youngest part of a calicle in $S$. $(A$. wellsi. The base of the tube is covered by choanosomal tissue exhibiting the choanocyte chambers $(a)$. The bottom of the calicle is closed by an organic tabula $(b)$. The black part $(c)$ are stained totipotent archaeocytes enclosed by tabulae. The lower tabula $(d)$ is becoming mineralized. The archaeocytes below the first archaeocyte chamber are totally enclosed by mineralized tabulae ( $f$ ). (Vacelet coll.) Scale $=300 \mu \mathrm{m}$. e Spirastrella cunctatrix Schmidt from the Mediterranean Sea near Banyuls sur Mer. The specimen exhibiting strong vertical canal systems comparable with the calicle systems in $S$. (Acanthochaetetes) wellsi. (SEM micrograph). f Spirasters of Spirastrella cunctatrix (SEM micrograph). $\mathrm{g}$ Tylostyles of Spirastrella cunctatrix (SEM micrograph) 
The soft tissue covers only the youngest calicle (Fig. 11a). The choanosome covers the calicle wall. The biggest space of the calicle is needed for the aquiferous excurrent system. The choanosome is anchored with the endopinacoderm at the basal skeleton. The choanocyte chambers are small and have a mean diameter of $20 \mu \mathrm{m}$ (Hartman and Goreau 1975; Vacelet 1981) (Fig. 11d). The surface of the sponge is covered by a dermal layer which is penetrated by incurrent pores and canals as well as superficial excurrent systems demonstrating an astrorhizal pattern. For further detailed descriptions, see Hartman and Goreau (1975). Very important is the occurrence of totipotent archaeocytes which are captured by tabulae in older parts of the calicles (Fig. 11d).

Secondary skeleton:

The sponge has an unique high $\mathrm{Mg}$-calcite skeleton. The entire skeleton exhibits a classical chaetetid structure (Fig. 11a). The microstructure of the skeleton is characterized by irregular lamellae of elongated $\mathrm{Mg}$-calcite crystals (for detailed descriptions and chemical compositions see Reitner and Engeser 1987). The calcite lamellae are present within a thin mucus layer between the exopinacoderm and the rigid calcitic skeleton. The thickness of the mucus layer is ca. $200 \mathrm{~nm}$, measured by one discrete, newly formed crystal layer. The newly formed crystals are needle-like and show a mean length of $2-4 \mu \mathrm{m}$ and diameter of less than 250 $\mathrm{nm}$. These primary crystals increase size by rapid epitactical crystal growth. The separate crystals grew together and formed a rigid calcareous body. Within the tabulae, the crystals are oriented more or less parallel. In some cases the crystals exhibit a random orientation. Within the empty calicles a randomly oriented high Mg-calcite cement ("back-fill") is observed (Fig. 11a).

Very common are asexual buds. The buds have their roots in one single calicle of the parent sponge. This budding feature stems from escaped, mobile, totipotent archaeocytes, forming a genetically identical sponge. The size of the calicles are mostly smaller than those seen in the parent sponge.

These simple procedure for skeletal formation is supported by stable isotope geochemical data. An equilibrium with seawater (high positive delta $\mathrm{C}^{13}(+4)$ and delta $\mathrm{O}^{18}$ (-0.9 data) is indicated (Reitner 1989b; Reitner and Grothe 1988).

\section{Spirastrella (Acanthochaetetes)-seunesi (Fischer) n.comb.}

This species is very common in Late Aptian to Late Albian Urgonian reefs with a worldwide distribution (Reitner 1989a).

Selected synonymy list:

1970 - Acanthochaetetes seunesi n.gen., n.sp. - Fischer, p. 201, Fig. 32, P1.

F, Figs. 3-5

1972 - Acanthochaetetes seunesi - Fischer and Lafuste, Figs. 1-7, Pl. 7

non 1973 - Acanthochaetetes seunesi - Cuif et al. Pl. 1, Fig. 6

1983 - Acanthochaetetes seunesi - Reitner and Engeser, P1. 1, Figs. 4-8

1987 - Acanthochaetetes seunesi - Reitner and Engeser, Figs. 2,4,6,8,10.

Description of the skeleton:

This sponge has straight or slightly curved tylostype megascleres and star-shaped spiraster microscleres. The microscleres do not show the extreme variation as seen 
in $S$.(A.) wellsi. The spicules are embedded within the calcitic skeleton. The megascleres have no preferred orientation within the secondary skeleton. The microscleres are quite often enriched within the tabulae. Megascleres are never entrapped within the tabulae. Within the calicle walls, microscleres are rare (further details see Reitner 1982, 1987d; Reitner and Engeser 1983, 1987). The structure and chemistry of the chaetetid basal skeleton is similar to $S$.(A.) wellsi. Some specimens show the same budding features as seen in $S$.(A.) wellsi.

Spirastrella (Acanthochaetetes) dendroformis n.sp. (Figs. 12b, c; 13d)

1983 - Acanthochaetetes ramulosus. - Reitner and Engeser, pp. 774-775, Pl. 1, Figs. 1-3.

1987d - Acanthochaetetes ramulosus. - Reitner, Pl. 18, Fig. 2

(not $A$. ramulosus Michelin)

Derivatio nominis: After the Creek word "dendr-" = tree shaped branches Holotype: Depository IPFUB, JR4/89 (Figs. 12a-c, 13a-d).

Material: Over 50 specimens

Locus typicus: Peña Albeniz near the village Araya, northern Spain.

Stratum typicum: Late Albian fore reef sediments of the Albeniz reef mound.

Diagnosis:

This sponge exhibits a ramified chaetetid basal skeleton. Structure and chemistry is similar to other $S$. (Acanthochaetetes). Only the axial part of the calcareous skeleton is irregularly arranged. In this part only few calicles separated by tabulae are visible. The intramural tylostyle megascleres are arranged radially within the

Fig. 12. Spirastrella (Acanthochaetetes) dendroformis n.sub. gen., n.sp. a Drawing of the ontogenetic older parts of the central zone of $S$. $(A$.) dendroformis exhibiting an irregular stromatoporoid structure of the basal skeleton and the spicule arrangement (aquiferous systems dotted). b Tylostyle megasclere. c Spiraster ("amphiaster")

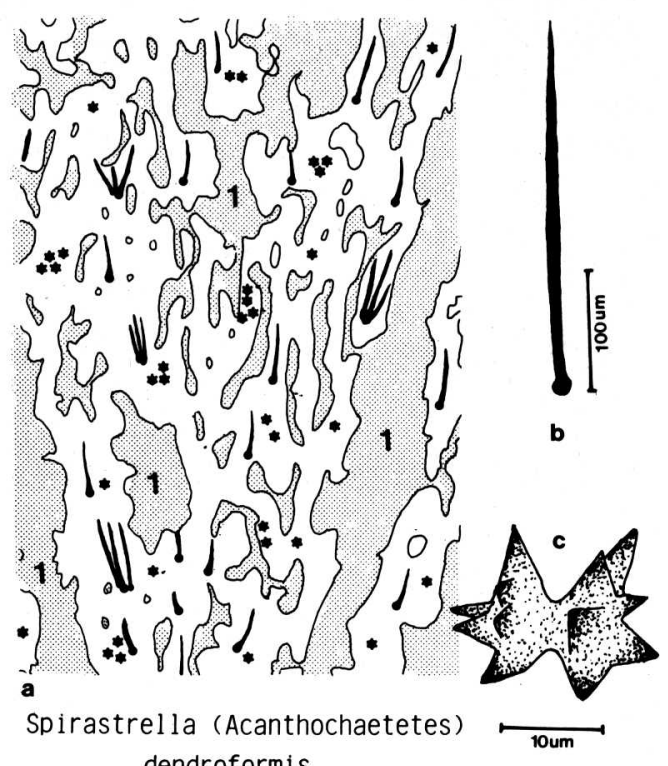

dendroformis 

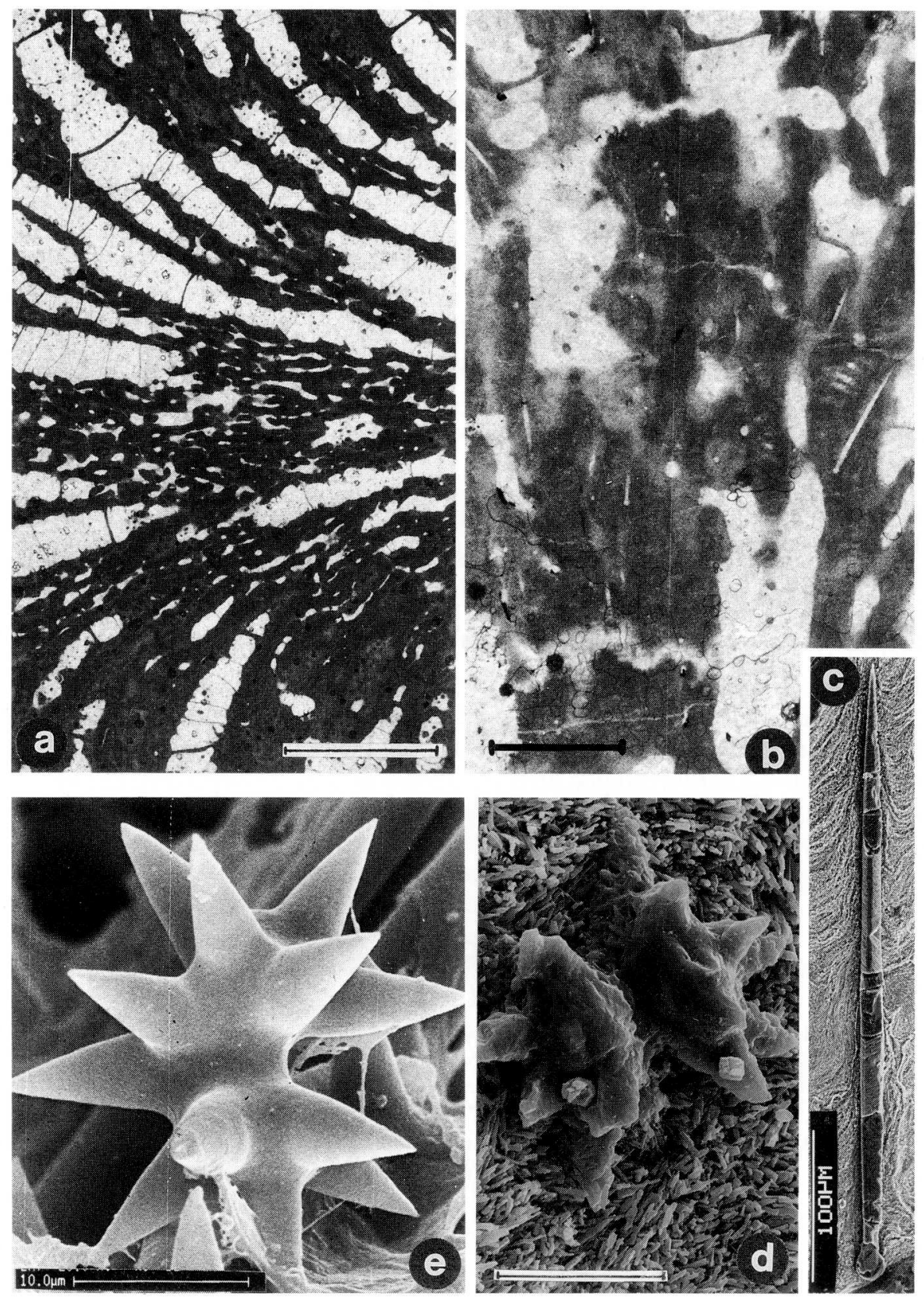

Fig. 13. a Micrograph of the holotype of Spirastrella (Acanthochaetetes) dendroformis demonstrating the central irregular zone and the chaetetid outer zone. Specimen from Late Albian reefs near Araya (northern Spain). Scale $=1 \mathrm{~mm}$. b Detail of the central zone of the holotype exhibiting the megascleres arrangement. Scale $=500 \mu \mathrm{m}$. $\mathrm{c}$ Tylostyle megasclere of $S$. (A.) dendroformis etched with titriplex acid. SEM micrograph.d Spiraster ("amphiaster") microsclere of S.(A.) dendroformis etched with titriplex acid. (SEM micrograph). e Spiraster microsclere of Spirastrella cunctatrix Schmidt (SEM micrograph) 
axial part. Microscleres are modified (“amphiaster”) spirasters, which are enriched within the axial part and tabulae of the outer part of the sponge.

Description of the holotype:

Spicular skeleton:

The spicular skeleton is composed of tylostyle megascleres with a length of 325-450 $\mu \mathrm{m}$ (mean $365 \mu \mathrm{m}$ ) (Figs. 12a-c, 13b,c) and spiraster microscleres mostly of amphiaster shape (Figs. 12a-c, 13d). The diameter varies from 25-35 $\mu$ m (mean $28 \mu \mathrm{m})$. The tylostyles are common in the central part and arranged in the same fan shaped pattern as observed by the tube systems (Fig. 13a,b). In some cases the spicules are arranged in small bundles which reflects the original radial pattern (Fig. 12a-c).

Some of the megascleres protrude into the open space of the calicle. Microscleres are common and mostly irregularly distributed (Fig. 12a-c). An enrichment is observed within the tube walls of the central part and the tabulae of the outer part.

Secondary skeleton:

From the holotype, three thin sections were made: the horizontally, vertically, and oblique section. The vertical median section has a length of $7.5 \mathrm{~cm}$. The stem has a thickness of $1.7 \mathrm{~cm}$. The irregular center part of the sponge varies from 5 $\mathrm{mm}-10 \mathrm{~mm}$. The center part is characterized by irregularly ascending tubes. The whole skeletal structure is fan shaped (Fig. 13a,b). Only a few tubes are separated by thin tabulae. The boundary between the center and the outer part is marked by a prominent tabulae layer. The outer part is characterized by a true chaetetid structure as seen in other acanthochaetetids. Microstructure and chemistry of the calcitic skeleton is similar to other Spirastrella (Acanthochaetetes) species. The inner calicle diameter varies from 320-520 $\mu \mathrm{m}$ (mean $433 \mu \mathrm{m}$ ). The outer calicle diameter varies from 480-1000 $\mu \mathrm{m}$ (mean $703 \mu \mathrm{m}$ ). Buds as seen in hemispherical species of $S .(A$.$) are not present.$

Differential diagnosis:

The new species exhibits close similarities with the secondary skeleton of Spirastrella (Acanthochaetetes) ramulosus (Michelin). But, in S.(A.) ramulosus, only few megascleres are observed and never spiraster microscleres. In $S$.(A.) seunesi (Fischer), no "amphiaster"-type spirasters are observed. Tylostyles are rare, never arranged in bundles, and never exhibit any radial pattern.

\section{Remarks:}

The spicular skeletons of all basal skeleton bearing spirastellids are similar to the species Spirastrella cunctatrix Schmidt (Figs. $11 \mathrm{e}-\mathrm{g}, 13 \mathrm{e}$ ). The extant $S$. (A.) wellsi (Hartman and Goreau) exhibits a wide variability of spiraster microscleres which is never observed within fossil forms. In S. cunctatrix microscleres are very abundant. The tylostyles are arranged in small bundles with a maximum of 20 scleres. Most bundles possess five to six spicules (Fig. 11g). Within the extant $S$.(A.) wellsi this feature is also observed. Within all fossil species, only $S$.(A.) dendroformis exhibits this feature. 
An unique feature is the presence of modified archaeocytes within the older portions of the calicles. These archaeocytes are comparable with gemmule bodies of freshwater sponges (Fig. 11d).

In some investigated a prominent vertical exhaltant tube system is observed, perhaps comparable with the calicles in Spirastrella (Acanthochaetetes) (Fig. 11e).

\section{Family Cassianothalamiidae Reitner (1987b)}

The affinities of this extinct coralline sponge group from the Late Triassic (Lower Carnian) with the order Hadromerida is based on the presence of spiraster microscleres. Besides spirasters, sterrasters and rare monaxonic megascleres are also observed. Atypical are the fusiform spicules.

\section{Cassianothalamia zardinii Reitner (1987b)}

1985 - ? Stylothalamia n.sp. - Reitner and Engeser, p. 170; P1. 4, Figs. 8-12

1987 - Cassianothalamia zardinii n.gen., n.sp. - Reitner, p. 573, P1. 1-3; P1. 4, Fig. 1

Primary and secondary skeleton:

The entire sponge exhibits a thalamid structure, convergent with the modern Vaceletidae. The thalamid collagenous skeleton was subsequently mineralised by an irregular micritic high Mg-calcite. A prominent spongocoel is present. Intramural spicules are rare. Mostly present are small spirasters, some bigger sterrasters, and very few monaxonic megascleres which rarely protrude into the open space of the chambers. The primary organic skeleton is marked by meniscus-shaped structures which cover the megascleres in the outer part of the vertical pillars (for further details see Reitner 1987b).

Remarks:

Cassianothalamia is probably a hadromerid sponge, based on the spirasters. The relationship to any extant Hadromerida is not known. The problem lies with the sterrasters, which are observed only in the Geodiidae, order Choristida, while the characteristic triaene megascleres are missing in Cassianothalamia. The hadromerid sponge Placospongia exhibits sterraster-like scleres (selenasters) beside small spirasters. Any further relationships are not known.

The thalamid or sphinctozoid rigid calcitic skeleton exhibits the same shape as the extant ceractinomorph sphinctozan sponge Vaceletia crypta (Vacelet).

\section{Functional Interpretation of the Observed Basal Skeleton Types}

Seven different secondary skeletal types are present within the Hadromerida. Five of them exhibit a chaetetid structure, one a thalamid, and one a modified crust, which is the simplest basal skeleton type. 
Chaetetid skeletons are known from two extant demosponges, Spirastrella (A.) wellsi Hartman and Goreau, linked to the Hadromerida, and Merlia normani Kirkpatrick, linked to the Poecilosclerida. One species from the Calcarea, $P e$ trobiona massiliana Vacelet, linked to the Calcaronea, is known, which contains a modified chaetetid skeleton (Reitner 1987a). In all three examples, the soft tissue of the active living sponge covers only the top of the skeleton and occupies only the youngest calicle. These sponges also produce totipotent archaeocytes enclosed in the older parts of the calicles. In $S$.(A.) wellsi the archaeocytes are separated from the active living sponge by organic or mineralized tabulae. In Merlia normani separation is also made by mineralized tabulae with a central hole and in Petrobiona the archaeocytes are located at the end of narrow canals within the basal skeleton (Vacelet 1988; Reitner 1987a; Reitner and Keupp 1989).

Besides the rigid Merlia normani a "soft" form is known which does not have any calcareous skeleton (Merlia deficiens sensu Vacelet 1980). Van Soest (1984) pointed out that both Merlia species are the same. This is important because the soft form does not construct any gemmule bodies. Both forms are probably ecotypes but the problem is, they occur together in same ecological niches. This feature is also observed in Spirastrella. The spicular skeleton of the subgenus Acanthochaetetes is closely related to Spirastrella. Acanthochaetetes has been restricted to deep fore reef areas and cryptic niches of coral reefs since the Lower Cretaceous and Spirastrella is not part of the Acanthochaetetes community (Reitner 1989a). An ecological controlling factor in the formation of the basal skeleton is proposed for Acanthochaetetes. This may be true for the calcisponge Petrobiona, which is located only in submarine caves and under huge rocks (Vacelet 1964; Reitner 1989a). The formation of a chaetetid or modified chaetetid skeleton is linked, in these cases, with ecological parameters. All modern demosponge chaetetid skeletons are secreted by the exopinacoderm and are not analogous to the primary skeleton of the sponge.

Within Chaetetes (Boswellia) mortoni, Chaetetopsis favrei, and Chondrochaetetes longitubus, the secondary skeleton is analogous to the primary skeleton. The living sponge occupied in these cases the ontogenetic youngest parts of the secondary skeleton. The thickness of the soft tissue is marked by the last tabulum. Archaeocytes may have been present within the extinct taxa. Besides the classic chaetetid skeletons, the ceratoporellid type of chaetetid skeleton is known, which is characterized by a rapid, early diagenetic, epitactical cementation of the older calicles. In this case, no totipotent archaeocytes can be protected. Probably all open chaetetid skeletons had the function of huge modified gemmule bodies. This idea is supported by the observation of small buds, which are connected to certain calicles of the parent sponge, as seen in $S$.(A.) wellsi.

The primary collagenous skeleton of the thalamid hadromerid sponge Cassianothalamia became calcified immediately after new chamber formation (Reitner 1987b). Common small asexual buds linked with the parent skeleton are observed. A formation from modified gemmules is probable.

Two further noncalcified hadromerids form gemmules, Cliona lobata and several types of the Suberites taxon. Gemmulue formation is therefore not restricted to haplosclerids. 
In $S$.(A.) dendroformis two ontogenetic stages of secondary skeletal formation are observed. In the early stage calcitic skeleton is analogous to the primary skeleton. The irregular tubes probably reflect the primary aquiferous system. Megascleres are common, regularly oriented, and exhibit, in some cases, the primary aggregates as seen in Spirastrella. The ontogenetic late stage is characterized by a normal acanthochaetetid skeleton which is not analogous to the primary sponge skeleton.

In Calcichondrilla the entire primary sponge skeleton became calcified. No chaetetid structure or special cavities for totipotent archaeocytes are observed. This basal crust is occasionally an important reef-frame stabilizer.

\section{Phylogenetic Theories (Figs. 14,15)}

To demonstrate possible phylogenetic relationships, the method of phylogenetic systematics was used. The Hadromerida and Tetractinellida are a monophylum, based on a number of well-defined synapomorphies (Hartman 1982; van Soest 1987). Van Soest (1987) has discussed three different cladograms based on the classification of Hartman (1982), his own ideas, and a cladogram based on a computer program developed by W.N. Ellis. In all three cladograms the Hadromerida and Tetractinellida are classified as a monophylum. Within the computer cladogram, the Chondrosiidae are grouped with the Vaceletidae, based on the lack of any spicules. Within the genus Chondrilla, asters are present. A close relationship between Chondrilla and Chondrosia is based on the similarity of the soft tissue and collagenous skeleton. Chondrosia is a chondrillid which lost its spicules. The Chondrosiidae must be classified within the monophylum Tetractinellida/Hadromerida.

There are three views on the significance of the secondary skeletons. Hartman and Goreau (1972) proposed that all calcareous basal skeleton bearing sponges are a monophylum and have created a separate class of sponges (Sclerospongiae). Van Soest (1984) and Vacelet (1985) pointed out the similarities of certain spicule skeletons with noncalcified demosponges. Van Soest (1984) suggested that calcified basal skeletons were developed only once and therefore an important plesiomorphy of the demosponges. Vacelet (1985) showed a polyphyletic origin of the calcified demosponges based on spicules similarities with noncalcified taxa. This idea was supported by Reitner (1987a,b), Reitner and Engeser $(1985,1987)$, Reitner and Keupp (1989), and Wood (1987), Wood and Reitner (1988), Wood et al. (1989) based on findings of many different spicule-bearing groups of calcified demosponges. These authors also pointed out the convergent nature of chaetetid, stromatoporoid, crust, and thalamid type of basal skeletons.

The two cladograms discussed here are based mainly on skeletal features to derive the phylogenetic significance of the secondary calcareous skeletons.

The analysis is based on the following features:

1. Radial pattern of megascleres

2. Asterose microscleres 
3. Tetractinellid spicules

4. Loss of tetractinellid spicules

5. Tylostyle or modified tylostyle spicules

6. Reduction of radiate pattern (subradiate)

7. Spiraster microscleres

8. Calcareous secondary skeleton (css)

8a. Chaetetid high Mg-calcite basal skeleton combined with internal stromatopororid basal skeleton and a remaining radial pattern of tylostyles.

8b. Chaetetid high Mg-calcite microlamellar-structured secondary skeleton without any similarities to the primary sponge skeleton.

8c. Chaetetid high $\mathrm{Mg}$-calcite irregularly structured secondary skeleton analogous to the primary collagenous/spicular skeleton.

8d. Chaetetid high Mg-calcite fascicular fibrous basal skeleton analogous to the primary collagenous/spicular skeleton.

8e. Chaetetid aragonitic fascicular fibrous basal skeleton analogous the primary skeleton.

8f. Thalamid high $\mathrm{Mg}$-calcite secondary skeleton analogous to the primary skeleton.

8g. Crust type or modified stromatoporoid $\mathrm{Mg}$-calcite secondary skeleton analogous to the primary skeleton.

9. Modified totipotent archaeocytes

10. Loss of asterose scleres

11. Reduction of megascleres

11a. Strong collagenous primary skeleton

12. No intramural spicules

13. Loss of megascleres

14. Loss of the entire spicular skeleton

15. Loss of the calcareous secondary skeleton

16. Burrowing ability in calcareous material

17. Clionid-type spirasters

\section{Theory I (Fig. 14)}

This theory is based on a close relationship between the Tetractinellida (Choristida) and Hadromerida. Two strong synapomorphies of these groups are the radiate or subradiate architecture of the megascleres (1) and the presence of asterose microscleres (2). The Choristida are characterized by four-rayed spicules (3) which are not present or lost within the Hadromerida (4). An important apomorphy of the Hadromerida are tylostyle or modified tylostyle scleres. Van Soest (1987) has placed the Tethyidae as a sister group of the Astrophorida (Choristida) because both groups exhibit a strong radiate pattern never observed in other Hadromerida and do not possess tylostyle spicules. The Cassianothalamidae ( $8 \mathrm{f}$ ) may show some affinities with the Tethyidae and must separate from the Hadromerida s.st.

A typical hadromerid group are the Spirastrellidae, which are characterized by spirasters (7) and some excavating species (16). The Clionidae based on spicule morphology and burrowing ability are a possible sister group of the Spirastrel- 


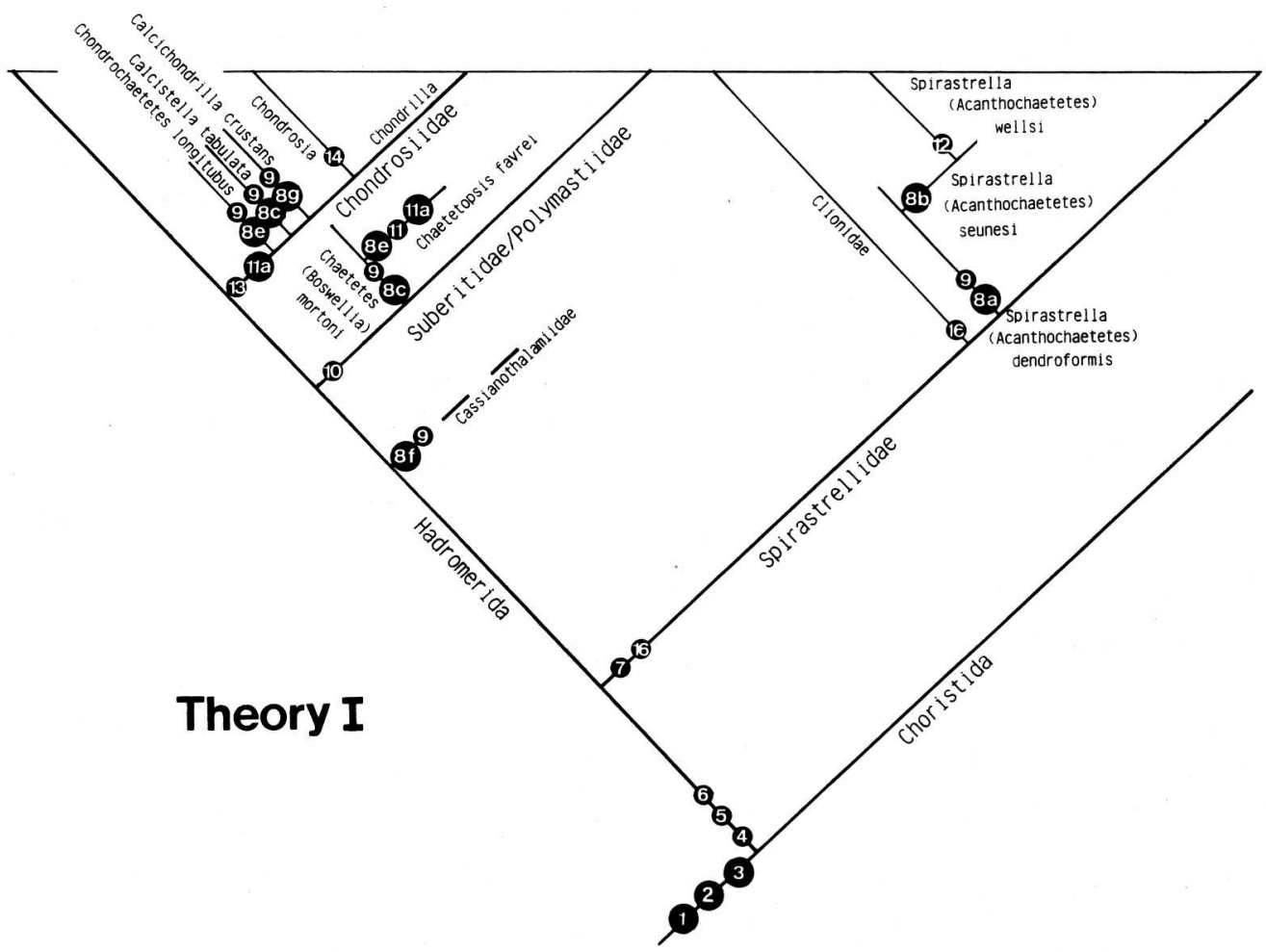

Fig. 14. Theory I. Cladogram demonstrating possible phylogenetic relationships bașed on a polyphyletic origin of the calcareous secondary skeletons. Character numbers see text

lidae. Important is the occurrence of a particularly high Mg-calcite chaetetid basal skeleton (8b) (Acanthochaetetes); a strong apomorphy of this sublineage. Related to this feature are modified totipotent archaeocytes. The oldest known representatives of this extant lineage were found in fore-reef and cryptic environments of Lower Cretaceous reef carbonates (occurrences from the Late Jurassic are doubtful) (Fischer 1970; Reitner and Engeser 1983, 1987). The specimens of the Lower Cretaceous exhibit a relatively high diversity (ca. six species) and some of them have intramural spicules. The younger forms have lost the intramural spicules (12). Besides the characteristic "adapted" chaetetid skeleton, one form is present which exhibits a combined chaetetid/stromatoporoid skeleton (8b). Probably this form is the primary one.

The Suberitidae/Polymastiidae are a sponge group in which the asterose microscleres are lost (10). The affinities to the Hadromerida is based on the relict radial pattern of the scleres. Boury-Esnault (1987) discussed this problem and concluded that the systematic position of this particular is open at the moment. For this present study the Suberitidae/Polymastiidae are placed within the Hadromerida. The oldest known (Lower Carboniferous) hadromerid sponge, is 
Chaetetes (Boswellia) mortoni. Boswellia possesses a chaetetid skeleton analogous to the primary skeleton, which is similar to the genus Suberites (8d). The Lower Cretaceous form Chaetetopsis favrei exhibits nearly the same type of chaetetid skeleton, and is probably evolved from Boswellia. In contrast to Boswellia, Chaetetopsis exhibits an aragonitic chaetetid skeleton (8e) and a reduced density of intramural spicules (11). The primary skeleton is probably replaced by a strong collagenous skeleton (11a).

The third group of Hadromerida which exhibits calcareous secondary skeletons are the Chondrillidae within the Chondrosida. The genus Chondrilla has lost the tylostyle megascleres (13) and is characterized by asterose microscleres enriched in an ectosomal crust. An important apomorphy of the Chondrosida is a strong collagenous skeleton (1 la). Three different basal skeletonś are observed. A classic chaetetid skeleton with a fascicular fibrous microstructure and rare intramural aster microscleres from the Carboniferous (Chondrochaetetes longitubus) (8d), a chaetetid skeleton with an irregular micritic microstructure with preserved remains of the aquiferous systems within the calicle walls and numerous asterose spicules (Calcistella tabulata) (8c), and the crust type or modified stromatoporoid calcitic basal skeleton of the genus Calcichondrilla $(8 \mathrm{~g})$ is observed. This form demonstrates a very close relationship with the extant noncalcified species Chondrilla grandistellata. All three basal skeletons are analogous to the primary skeleton. Within the genus Chondrosia, the whole spicular skeleton is lost (14). Based on this theory, the secondary calcareous basal skeletons have developed independently seven times from noncalcified ancestors and are therefore convergent. The entire structure and function of the secondary skeleton are different. The chaetetid type skeleton is probably linked with the occurrence of totipotent archaeocytes and therefore these skeletal types are modified gemmule bodies. Basal skeleton formation is probably related to ecological parameters.

\section{Theory II (Fig. 15)}

The main problem with theory $I$ is the independent development of secondary skeletons. According to van Soest (1984), calcareous secondary skeletons are a plesiomorphic feature of the Demospongiae. This eliminates the problem of a repeated origin for calcareous basal skeletons. Within Calcarea, both subclasses, the Calcinea and Calcaronea, evolved from rigid basal skeleton-bearing forms. The Murrayonida are probable ancestors of the modern Calcinea and the Minchinellida of the nonrigid modern Calcaronea (Reitner 1987a). Interpreting the basal skeletons as a plesiomorphic feature of the Hadromerida clade, it is much easier to explain the common occurrence of calcareous secondary skeletons. Based on this theory, the modern noncalcified forms are evolved from basal skeleton-bearing forms. This view is supported by the fossil record. Most fossil Hadromerida have only formed a basal skeleton, excepting Cliona. In this clade Cliona is related to Spirastrella as a sister group. Both have lost the calcareous skeleton (15) and have a burrowing ability (16). All clionids burrow and are characterized by elongated spirasters (17), a good autapomorphy of this taxon, Isolated asterose and tylostyle spicules which are common in Mesozoic sediments 


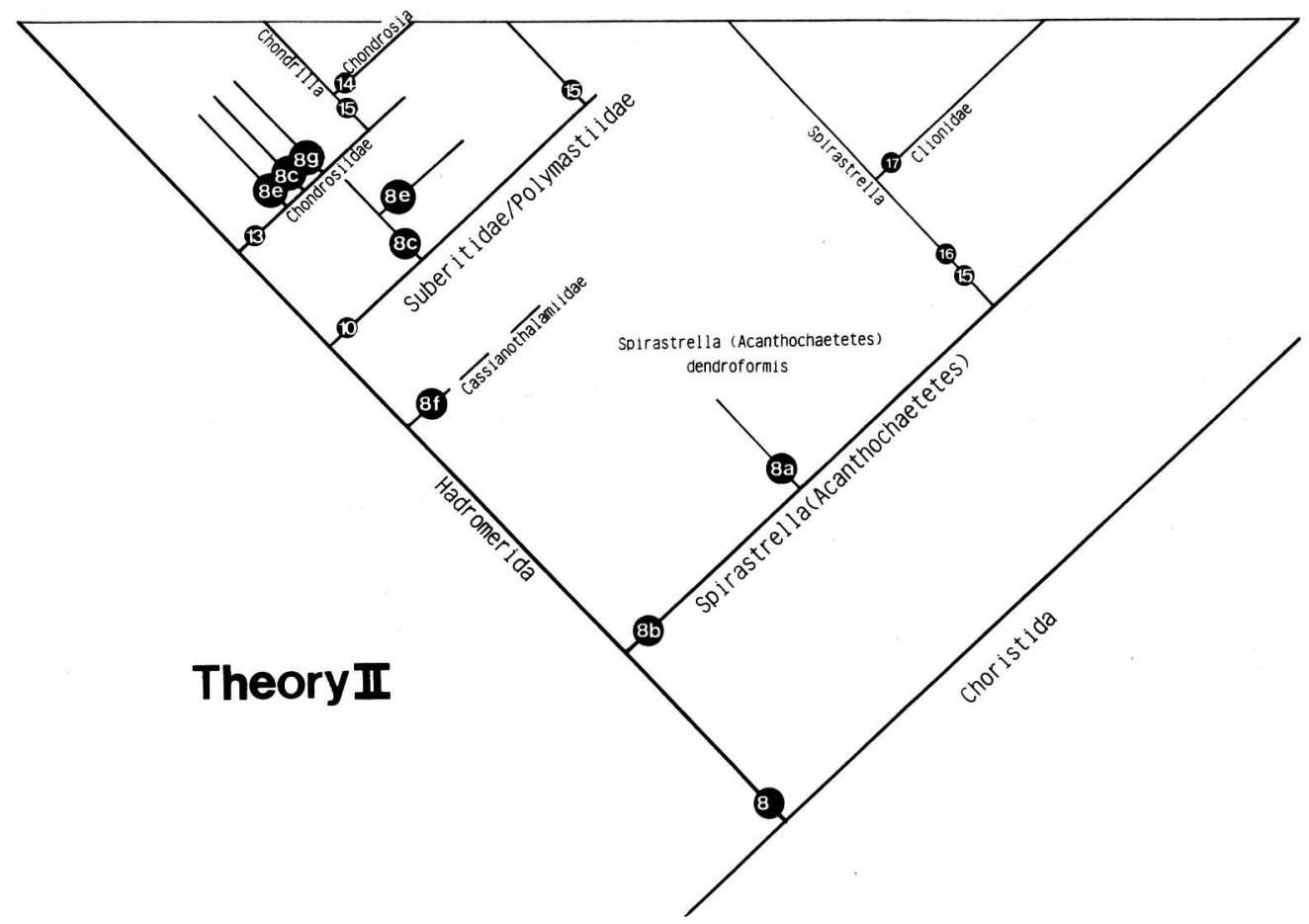

Fig. 15. Theory II. Cladogram based on the monophyletic origin of the calcareous basal skeleton. Character numbers see text

may be of hadromerid origin. But both spicule types occur also in other sponge groups.

The main criticism about this theory is the different micro- and ultrastructures as well as different mineralogies of the basal skeletons. To decide which theory is correct, we must know more about the ontogeny of young sponges after settlement of the larva. No data are available at this time from these particular sponges. Basal skeletons are definitely not a plesiomorphic character of the entire Demospongiae, but single clades can evolve from calcareous rigid skeleton bearing ancestors.

A monophyletic origin of the calcareous skeletons of the Hadromerida cannot be fully excluded, but this opinion must be proven by studies of the early ontogeny of these sponges (e.g., Acanthochaetetes). A further problem are the preservation potentials of nonrigid sponges. We do not know much about "soft" demosponges in the past. Only isolated scleres are common and in most cases the entire spicula sponges skeleton is not known. It is very probable that "soft" Hadromerida have existed since early Mesozoic time.

Based on this current knowledge a polyphyletic/convergent nature of the basal skeletons of the Hadromerida is most probable. 


\section{Conclusions}

a) The Hadromerida s.str. are a monophyletic sponge group in which three types of skeletal formations are observed: (1) primary skeleton composed of collagenous skeletal material and siliceous micro- and megascleres which can be reduced or lost; (2) secondary calcareous basal skeletons; and (3) indirect basal skeleton formation by excavating burrows.

b) Five different chaetetid skeletons are observed. Four of them are analogous to the primary sponge skeleton. Only one does not exhibit any similarities with the primary skeleton (Acanthochaetetes). In all cases the chaetetid skeletons can be explained as modified gemmule bodies in which totipotent archaeocytes are present. Besides the chaetetid skeletons, one crust type or modified stromatoporoid skeleton (Calcichondrilla), and one thalamid skeleton are observed (Cassianothalamia).

c) Only three new asterose spicules-bearing taxa are described: Calcistella tabulata n.gen. n.sp. from the Lower Cretaceous of Greece, Chondrochaetetes longitubus n.gen.n.sp. from the Carboniferous of Russia, and Calcichondrilla crustans n.gen. n.sp. from the Lower Cretaceous of northern Spain. All three new genera are classified within the chondrosiidae.

The chaetetid genus Acanthochaetetes is included as a subgenus within the genus Spirastrella based on the similarity of the spicular skeleton. One new species is described: Spirastrella (Acanthochaetetes) dendroformis n.sp. It is characterized by an internal stromatoporoid skeleton with radially oriented spicules and a normal chaetetid adult structure.

d) The Cassianothalamiidae are probably linked with the Tethyidae.

e) The fossil species Chaetetes (Boswellia) mortoni Gray and Chaetetopsis favrei (Deninger) are classified within the tylostyle-bearing Hadromeria (Suberitidae/Polymastiidae).

f) Two phylogenetic theories in which the origin and significance of the different basal skeletons are discussed. A polyphyletic origin is, based on the current knowledge, probable. A monophyletic origin cannot be fully excluded, if the young adult sponges do not possess any calcareous skeletons.

Acknowledgments. I am indebted to Prof. J. Vacelet (Station Marine Endoume Marseille), Prof. H. Keupp, Dipl. Biol. F. Grothe (Freie Universität Berlin), Dr. R. van Soest (Zoological Institute Amsterdam), and Miss S. Stone, curator of the sponge section of the British Museum N.H. in London, for the permission to study specimens in their collections and some donations. I thank Dr. B. Gierlowski-Kordesch (Freie Universität Berlin) for translational assistance. The Deutsche Forschungsgemeinschaft is acknowledged for financing this investigation $(\operatorname{Re} 6651-1)$.

\section{References}

Bergquist PR (1978) Sponges. Hutchinson, University of California Press, pp 268

Boury-Esnault N (1987) The Polymastia species (Demosponges, Hadromerida) of the Atlantic Area. In: Vacelet J, Boury-Esnault N (eds) Taxonomy of Porifera. Nato Asi Ser G13, Springer, Berlin Heidelberg New York Tokyo, pp 29-66 
Cuif J-P, Feuillee P, Fischer J-C, Pascal A (1973) Prèsence d'Astrorhizes chez les Chaetetida Mèsozoiques. CR Acad Sci Paris 277:2473-2476

Deng Z (1982) Mesozoic Milleporina and tabulatomorphic corals from Xizang. Paleontol Xizang 4:184-188

Deninger K (1906) Einige neue Tabulaten und Hydrozoen aus Mesozoischen Ablagerungen. N Jahrb Min Geol Paläontol 1:61-70

Döderlein L (1897) Über die Lithonina, eine neue Gruppe von Kalkschwämmen. Zool Jahrb $10: 15-32$

Fischer J-C (1970) Rèvision et essai de classification des Chaetetida (Cnidaria) post-paleozoiques. Ann Palèontol (Invert) 56:151-220

Fischer J-C, Lafuste J (1972) Nouvelles observations sur la palèohistologie du genre Acanthochaetetes (Hydrozoa, Chaetetida). Bull Soc Geol Fr 14(7):320-324

Gray D (1980) Spicule pseudomorphs in a new Paleozoic chaetetid, and its sclerosponge affinities. Palaeontology 23:803-820

Hartman WD (1979) A new sclerosponge from the Bahamas and its relationship to Mesozoic stromatoporoids. Coll Int CNRS 291:467-474

Hartman WD (1982) Porifera. In: Parker SP (ed) Synopsis and classification of living organisms. McGraw-Hill, New York, pp 640-666

Hartman WD, Goreau TF (1970) Jamaican coralline sponges: their morphology, ecology, and fossil relatives. In: Fry WG (ed) The biology of Porifera. Symp Zool Soc Lond 25:205-243

Hartman WD, Goreau TF (1972) Ceratoporella (Porifera: Sclerospongiae) and the chaetetid "corals". Trans Conn Acad Arts Sci 44:133-148

Hartman WD, Goreau TF (1975) A Pacific tabulate sponge, living representative of a new order of sclerosponges. Postilla 167:1-14

Kazmierczak J (1979) Sclerosponge nature of chaetetids evidenced by spiculated Chaetetopsis favrei (Deninger 1906) from the Barremian of Crimea. N Jahrb Geol Paläontol Mh 1979:98-108

Kirkpatrick R (1908) On two new genera of recent pharetronid sponges. Ann Mag Nat Hist 8:503-514

Kirkpatrick R (1910) On a remarkable pharetronid sponge from Christmas Island. Proc R Soc $83: 124-133$

Kirkpatrick R (1911) On Merlia normani, a sponge with a siliceous and calcareous skeleton. QJ Microsc Sci 56:657-702

Levi C (1973) Systematique de la classe Demospongiaria (demosponges). In: Grasse PP (ed) Traitè de Zoologie III(1) Masson, Paris, pp 577-631

Lister JJ (1900) Astrosclera willeyana, the type of a new family of sponges. In: Willey A (ed) Zool Results Part 4:461-482

Mori K (1976) A new sclerosponge from Ngargol, Palau Island and its fossil relatives. Tohoku Univ Sci Rep 2 Ser Geol 46:1-9

Mori K (1977) A calcitic sclerosponge from the Ishigaki-shima coast, Ryukyu Islands, Japan. Tohoku Univ Sci Rep 2 Ser Geol 47:1-5

Peterhans E (1930) Etude du genre Chaetetopsis Neumayr et classification nouvelle des Chaetètidès. Eclogae Geol Helv 22:81-85

Reitner J (1982) Die Entwicklung von Inselplattformen und Diapir-Atollen im Alb des BaskoKantabrikums (Nordspanien). N Jahrb Geol Paläontol Abh 165:87-101

Reitner J (1987a) Phylogenie und Konvergenzen bei rezenten und fossilen Calcarea (Porifera) mit einem kalkigen Basalskelett (“Inozoa, Pharetronida”). Berl Geowiss Abh 86:87-125

Reitner J (1987b) A new calcitic sphinctozoan sponge belonging to the Demospongiae from the Cassian Formation (Lower Carnian; Dolomites, Northern Italy) and its phylogenetic relationship. Geobios 20:571-589

Reitner J(1987c) Euzkadiella erenoensis n.gen.n.sp. ein Stromatopore mit spikulärem Skelett aus dem Oberapt von Ere.o (Prov Guipuzcoa, Nordspanien) und die systematische Stellung der Stromatoporen. Paläontol Z 61:203-222

Reitner J (1987d) Mikrofazielle, palökologische und paläogeographische Analyse ausgewählter Vorkommen flachmariner Karbonate im Basko-Kantabrischen Strike Slip Fault-Becken-System (Nordspanien) an der Wende von der Unterkreide zur Oberkreide. Doc Nat 40:1-248

Reitner J (1989) Lower and Mid-Cretaceous Coralline Sponge Communities of the Boreal and Tethyan Realms in Comparison with the Modern Ones - Palaeoecological and Palaeogeographic 
Phylogenetic Aspects and New Descriptions of Spicule-Bearing Hadromerid Sponges

Implications. - In: Wiedmann J (ed) Cretaceous of the Western Tethys. Proceedings 3rd International Cretaceous Symposium, Tübingen 1987, pp 851-878. E Schweizerbart'sche Verlagsbuchhandlung, Stuttgart

Reitner J (1989b) Struktur, Bildung und Diagenese der Basalskelette bei rezenten Pharetroniden unter besonderer Berücksichtigung von petrobiona massiliana Vacelet \& Levi 1958 (Minchinellida, Porifera). Berl Geowiss Abh (A) 106:343-384

Reitner J, Engeser TS (1983) Contributions to the systematics and the paleoecology of the family Acanthochaetetidae (Fischer 1970) Order Tabulospongida, Class Sclerospongiae. Geobios 16:773-779

Reitner J, Engeser TS (1985) Revision der Demospongier mit einem thalamiden, aragonitischen Basalskelett und trabekulärer Internstruktur ("Sphinctozoa" pars). Berl Geowiss Abh 60:151-193 Reitner J, Engeser TS (1987) Skeletal structures and habitats of Recent and fossil Acanthochaetetes (subclass Tetractinomropha, Demospongiae, Porifera). Coral Reefs 6:151-157

Reitner J, Grothe F (1988) Origin of the basal skeleton of Petrobiona massiliana Vacelet (Calcaronea, "Pharetronida"). Berl Geowiss Abh 100:29

Reitner J, Keupp H (1989) Basalskelette bei Schwämmen - Beispiel einer polyphyletischen Entwicklung. Geowissenschaften 1989:71-78

Reitner J, Cuffey RJ, Scott RW Albian coralline sponge, Caribbean Province, Arizona. N Jahrb Geol Paläont Mh (in press)

Rios JM, Almela YA (1944) Un Chaetetido del Eoceno español. Notas Comun Inst Geol Min Esp 12:19-37

Rützler K (1974) The burrowing sponges of Bermuda. Smithsonian Contrib Zool 165:203-216

Vacelet J (1964) Etude monographique de l'eponge calcaire Pharetronide de Mediterranèe, Pe trobiona massiliana Vacelet \& Levi. Les Pharetronides actuelles et fossiles. Recl Trav St Mar Endoume 50:1-125

Vacelet $\mathbf{J}$ (1980) Squelette calcaire facultatif et corps de regènèration dans le genre Merlia, éponges apparentèes aux Chaetètidès fossiles. CR Hebd Seances Acad Sci Paris 290:227-230

Vacelet J (1981) Eponges hypercalcifièes ("Pharetronides", "Sclerosponges") des cavites recifs coralliens de Nouvelle-Caledonie. Bull Mus Natl Hist Paris 4 Ser $31981 \mathrm{sec}$ a 2:313-351

Vacelet J (1985) Coralline sponges and the evolution of Porifera. In: Conway Morris S, George JD, Gibson R, Platt HM (eds) The origins and relationships of lower invertebrates. Syst Assoc Spec Vol 28:1-13

Vacelet J (1988) The storage cells of calcified relict sponges. In: Proceedings Third Internat conf Sponge Biol. Smithsonian Inst Press, Washington, DC

Vacelet J, Garrone R (1985) Two distinct populations of collagen fibrils in a "sclerosponge" (Porifera). In: Bairati A, Garrone R (eds) Biology of invertebrate and lower vertebrate collagens. NATO ASI Ser ser A: Life Sciences 93. Springer, Berlin Heidelberg New York, pp 183-189

Van Soest RWM (1984) Deficient Merlia normani Kirkpatrick, 1908, from the Curacao reefs, with a discussion on the phylogenetic interpretation of sclerosponges. Bijdr Dierkd 54:211-219

Van Soest RWM (1987) Phylogenetic exercises with monophyletic groups of sponges. In: Vacelet J, Boury-Esnault N (eds) Taxonomy of Porifera. NATO ASI Ser, ser G: Ecol Sci 13. Springer, Berlin Heidelberg New York, pp 227-241

Wiedenmayer F (1977) Shallow-water sponges of the western Bahamas. Exper Suppl 28:287

Wood R (1987) Biology and revised systematics of some Late Mesozoic stromatoporoids. Spec Pap Paleontol 37:1-89

Wood R, Reitner J (1988) The "chaetetid" demosponge Stromatoaxinella irregularis (Michelin) and its systematic implications. N Jahrb Geol Paläontol Mh 1988:213-224

Wood R, Reitner J, West R (1989) Systematics and phylogenetic implications of the haplosclerid stromatoporoid Newellia mira nov. gen. Lethaia 22 